\title{
LA SOLIDARIDAD COMO PRINCIPIO CONSTITUCIONAL
}

\author{
FRANCISCO FERNÁNDEZ SEGADO \\ Catedrático de Derecho Constitucional \\ Universidad Complutense de Madrid
}

SUMARIO

I. Aproximación al concepto de solidaridad.

II. El devenir histórico de la idea de solidaridad.

III. El principio de solidaridad en el Estado social de la segunda postguerra.

IV El principio de solidaridad en la Constitución de 1978

\section{APROXIMACIÓN AL CONCEPTO DE SOLIDARIDAD.}

La solidaridad, como bien se ha señalado ${ }^{1}$, es una noción más fácil de intuir que de definir y delimitar por su contenido, alcance y aplicación, y si ello es así con carácter general, aún lo es más cuando, incorporada a un texto constitucional, se convierte en un auténtico principio vertebrador de esa norma fundamental, como acontece en el caso de la Constitución de 1978.

Innecesario es decir, que en el plano de la ética la solidaridad aparece como una virtud moral; puede afirmarse que nos hallamos ante un auténtico valor ético-moral que bien podría compendiarse en la idea de fraternidad. Ser solidario, en pocas palabras, es asumir como propio el interés de un tercero, identificarse con él, hacerse incluso cómplice de los intereses, desvelos e inquietudes de ese otro ser humano². En el ámbito de lo social,

1 DE JUAN Y PEÑALOSA, J.L: «El principio de solidaridad interregional. El principio de solidaridad y la regionalización de los impuestos», en Documentación Administrativa, nº 181, Enero/Marzo 1979, págs. 191 y ss.; en concreto, pág. 191.

2 Bien es verdad, que no se ha dejado de objetar por algunos - y de ello se ha hecho eco Cortina — que la solidaridad viene a introducir una relación de asimetría entre el que ejerce la solidaridad y el que se beneficia de ella, relación que supone una cierta superioridad por parte del primero y de inferioridad por parte del segundo. De ahí que se diga que es más digno para el beneficiario saber que el beneficio puede ser mutuo, que sentirse unilateralmente beneficiado, y de ahí que se considere que la cooperación aumenta la autoestima en mayor medida que la solidaridad. Cfr. al respecto, CORTINA ORTS, A: «Más allá del colectivismo y el individualismo», en Sistema. Revista de Ciencias Sociales, n 96, Mayo 1990, págs. 3 y ss.; en concreto, pág. 12. 
la solidaridad constituye un ingrediente esencial, la verdadera «conditio sine qua non» de la existencia de un grupo social, pues, como con toda razón se ha apuntado ${ }^{3}$, sin solidaridad no hay muchas posibilidades de que exista un grupo humano digno de tal nombre. El gran sociólogo frances Émile Durkheim (1858-1917), a partir de la idea de vinculación entre el individuo y la comunidad social en que se integra ${ }^{4}$, vino a pensar en la solidaridad como la esencia misma de la moralidad, el ideal moral, porque conjugaría la autonomía personal con la integración social ${ }^{5}$. Su pensamiento era en buena medida tributario del de Pierre Leroux (1797-1871), quien hizo de la solidaridad una especie de característica antropológico-social, que la convertía en la base de la vida social, concepción que también haría suya su coetáneo Auguste Comte (1798-1857) ${ }^{6}$. No ha de extrañar que, en sintonía con todo ello, la solidaridad se haya considerado la virtud social por excelencia, en cuanto que, objetivamente, presupone una relación de pertenencia y, por lo mismo, de asunción de una corresponsabilidad, que vincula al individuo con el grupo social del que forma parte.

La solidaridad, conjuntamente con la libertad, la igualdad y la justicia, han venido a conformar la que creo que bien podría tildarse de tetralogía axiológica del Estado social de nuestro tiempo. Ciertamente, la solidaridad ha sido una noción de menor relevancia dogmática que, por ejemplo, las de libertad e igualdad ${ }^{7}$, pero lo cierto es que, con el devenir del tiempo, la solidaridad, piedra angular de la herencia cultural del humanismo cristiano, se ha convertido en un valor de referencia meta-ideológico, o lo que es igual, en una referencia axiológica general reivindicada desde cualquier posición ideológica ${ }^{8}$.

Los valores se depositan en la historia, conforman la organización social, pero son fruto, como ha escrito Coturri ${ }^{9}$, de largos procesos de maduración colectiva, con vicisitudes muy diversas, siendo el proceso de fondo eminentemente cultural. No ha de extrañar por lo mismo que, en su excelente estudio de la historia social de la idea de soli-

3 SOLANO SANTOS, L.F: «La solidaridad social, objetivo último de las relaciones públicas», en Documentación de las Ciencias de la Información, Vol. 32, 2009, págs. 267 y ss.; en concreto, pág. 280.

4 En realidad, Durkheim lo que fue es consciente no sólo de la influencia individualista en la sociedad, sino también de sus nefastas consecuencias; de ahí que, como se ha dicho, Durkheim eligiera a la propia sociedad como la panacea, como el remedio de todos los males, una sociedad, eso sí, regida por la idea que venimos tratando. BUCK AVELINO, P: «Princípio da solidariedade: imbricaçôes históricas e sua inserçâo na Constituiçâo de 1988», en Revista de Direito Constitucional e Internacional, Ano 13, n 53, Outubro/Dezembro 2005, págs. 227 y ss.; en concreto, pág. 242.

5 Apud DE LUCAS, J: «La polémica sobre los deberes de solidaridad», en Revista del Centro de Estudios Constitucionales, nº 19, Septiembre/Diciembre 1994, págs. 9 y ss.; en concreto, pág. 23.

6 Cfr. al respecto AMENGUAL, G: «La solidaridad como alternativa. Notas sobre el concepto de solidaridad», en Revista Internacional de Filosofía Política, no 1/1993, Enero 1993, págs. 135 y ss.; en concreto, pág. 136.

7 Como recuerda González Amuchastegui, ello ha sido así también para la Filosofía moral y política. Cfr. al respecto, GONZÁLEZ AMUCHASTEGUI, J: «Notas para la elaboración de un concepto de solidaridad como principio político», en Sistema. Revista de Ciencias Sociales, nº 101, Marzo 1991, págs. 123 y ss.; en concreto, pág. 125 .

8 JIMÉNEZ REDONDO, J.C: El valor de la solidaridad en un mundo global, CEU Ediciones, Madrid, 2010, págs. 11-12.

9 COTURRI, G: «Las bases políticas de la solidaridad», en Anales de la Cátedra Francisco Suárez (monográfico sobre «Italia, años 80. Derecho, política y democracia»), n 30/1990, págs. 129 y ss.; en concreto, pág. 137. 
daridad en la Francia decimonónica, Hayward se haya hecho eco de los bruscos cambios de fortuna por los que tal idea ha atravesado ${ }^{10}$, en lo que quizá tenga bastante que ver la indeterminación y vaguedad del propio concepto ${ }^{11}$.

El término «solidaridad» encuentra su raíz en el étimo romano solidarium, que se enlaza con las expresiones solidum, soldum, y que significa «entero», «compacto», y de ahí la conocida figura jurídica de la obligatio in solidum, en la que cada uno de los codeudores asume la totalidad de la obligación contraída, y cada uno de los coacreedores dispone del derecho de exigir el cumplimiento de la obligación en su totalidad. Es claro que en el mundo del Derecho el concepto de «solidaridad» puede considerarse una herencia del Derecho romano recepcionada por el Código Civil napoleónico de $1804^{12}$. Esta instrumentación jurídica iusprivatista de la noción de solidaridad va a cumplir una función eminentemente garantista: la de reforzar y asegurar las garantías del acreedor, y por lo mismo la propiedad, y del tráfico jurídico, que es tanto como decir la libertad económica, lo que ya nos pone de manifiesto no sólo el acentuado individualismo de una figura que cumple semejante rol, con su consiguiente apartamiento de la visión de la misma por los teólogos social-católicos — pensemos en Joseph de Maistre (1753-1821)_, sino incluso su desnaturalización desde los parámetros con los que la solidaridad es visualizada en el Estado social de nuestro tiempo. Ello es obvio si se atiende a los derroteros bien diversos a que responde la lógica de la solidaridad en el Estado social de nuestro tiempo. En el análogo sentido, Vidal ha podido escribir ${ }^{13}$, que la solidaridad, entendida como Derecho desde el paradigma iusprivatista, es una solidaridad egoísta, y contradictoria con la solidaridad vista como valor jurídico en el marco del Estado social y democrático de Derecho.

Innecesario es reiterar la trascendencia que la solidaridad ha adquirido en el ámbito del Derecho público y, más precisamente, en el marco del constitucionalismo de nuestro tiempo, esto es, del Derecho constitucional del Estado social y democrático de Derecho. Cierto es que no han faltado autores que han considerado que el Derecho no es el ámbito propio de la solidaridad. Así, Cortina cree que la solidaridad es incompatible con la coacción jurídica y, por lo tanto, cualquier intento de anudar consecuencias jurídicas a la solidaridad (así, por ejemplo, extraer de ella deberes exigibles en último término mediante la coacción jurídica) significaría tanto como la destrucción de la noción misma de solidaridad ${ }^{14}$. No podemos compartir tal posición, que además la propia realidad jurídica desmiente, en cuanto que la recepción al máximo nivel jurídico de la solidaridad, como principio constitucional, ha supuesto su plena normativización, su ope-

10 HAYWARD, J.E.S.: «Solidarity: the Social History of an Idea in Nineteenth Century France», en International Review of Social History, Vol. 4, No. 2, 1959, págs. 261 y ss.; en concreto, pág. 269.

11 «It can be argued - escribe Hayward - that the concept of solidarity is extremely vague and indeterminate if used without qualification; without prefix or suffix that gives it a distinctive orientation». HAYWARD, J.E.S: «Solidarity: the Social History...», op. cit., pág. 261.

12 Como recuerda Hayward, la concepción jurídica de una relación de solidaridad entre los miembros de una sociedad presenta su primera señal oficial en Francia en la sección cuarta, del capítulo $4^{\circ}$ del Título III del Código Civil, titulado: «Des obligations solidaires». HAYWARD, J.E.S: «Solidarity: the Social History...», op. cit., pág. 270.

13 VIDAL GIL, E.J: «Sobre los derechos de solidaridad. Del Estado liberal al social y democrático de Derecho», en Anuario de Filosofía del Derecho, tomo X, 1993, págs. 89 y ss.; en concreto, pág. 100.

14 Apud DE LUCAS, J: «La polémica sobre los deberes de solidaridad», op. cit., pág. 16. 
ratividad como principio jurídico. Más aún, el art. $2^{\circ}$ de la Constitución italiana vinculó de modo específico la solidaridad al cumplimiento de unos determinados deberes, pues no en vano alude a los «doveri inderogabili di solidarietà politica, economica e sociale». Cierto es, como apunta la doctrina ${ }^{15}$, que como todos los principios vértices de gran contenido ético y político, la solidaridad es difícil de tecnificar en normas jurídicas concretas, pero ello, añadiríamos por nuestra cuenta, no significa que no puedan extraerse de la solidaridad, en cuanto principio constitucional, que ha de ser interpretado en conexión con otras normas constitucionales, precisas consecuencias jurídicas en ámbitos materiales diversos.

Y a todo ello bien podría añadirse que la constitucionalización de un principio, que a la par es un valor, como el de la solidaridad opera como elemento de fundamentación del propio orden político. Refiriéndose a Italia, Galeotti, en un espléndido trabajo, ha puesto de relieve que la solidaridad debe ser reconocida como principio «fondante della nostra convivenza di Stato democratico», en cuanto aparece vinculada de modo inescindible (en el propio $\operatorname{art}^{\circ} .2^{\circ}$ ) con el principio personalista ${ }^{16}$. Pensemos, en estrecha conexión con la idea precedente, en que la función prestacional del Estado (que un sector de la doctrina, Bobbio muy destacadamente, también identifica como función promocional del Derecho y del Estado), exigida justamente por los derechos que responden a esa misma calificación de derechos prestacionales, encuentra en el valor de la solidaridad un más que relevante punto de sustento.

\section{EL DEVENIR HISTÓRICO DE LA IDEA DE SOLIDARIDAD}

Al abordar el itinerario histórico de la solidaridad, Peces-Barba distinguió entre la solidaridad de los antiguos, que arranca de la cultura clásica, se prolonga en la Edad Media y también en la moderna hasta el siglo XVIII, y la solidaridad de los modernos ${ }^{17}$. Mientras la primera presenta básicamente una dimensión ética y religiosa, en la que la solidaridad se contempla como virtud, la segunda surgirá como un rechazo frente a una determinada visión de la economía política, la que, en nombre del principio del laissez faire, construirán los fisiócratas y, de modo muy particular, los economistas británicos Adam Smith (1723-1790) y Thomas Robert Malthus (1766-1834) ${ }^{18}$. Esta nueva visión de la solidaridad comenzará a ser teorizada en estrecha conexión con el pensamiento de la Ilustración, latiendo en ella un rechazo de la concepción antisolidaria latente en esas doctrinas económicas que propugnaban un modelo asentado en la lucha individual por la

15 PÉREZ MORENO, A: «Técnicas jurídicas garantizadoras del principio de solidaridad regional», en Estudios sobre el Proyecto de Constitución, Centro de Estudios Constitucionales, Madrid, 1978, págs. 703 y ss.; en concreto, pág. 708. 6.

16 GALEOTTI, S: «Il valore della solidarietà», en Diritto e Società, 1996/1, págs. 1 y ss.; en concreto, pág.

17 Cfr. al respecto, PECES-BARBA MARTÍNEZ, G: Curso de Derechos Fundamentales, I (Teoría general), EUDEMA, Madrid, 1991, págs. 222 y ss.

18 Recuérdese la famosa parábola del banquete, que Malthus incluye en la segunda edición de su célebre obra On Population, («Ensayo sobre la población»), en la que sostiene que «la felicidad del conjunto será resultado de la felicidad de los individuos y se iniciará primero en ellos. No se requiere una cooperación».

UNED. Teoría y Realidad Constitucional, núm. 30, 2012, pp. 139-181. 
existencia, con la subsiguiente consagración de las desigualdades, y el empleo puramente utilitario de la fuerza de trabajo.

Se viene admitiendo ${ }^{19}$ que será el filósofo y político liberal y progresista francés, marqués de Condorcet (1743-1794), cuya teorización sobre el progreso anuncia la obra de Comte, quien inspire el primer reconocimiento jurídico-político, incluso constitucional, de la solidaridad. Basta al respecto con traer a la memoria el Proyecto de Constitución de diciembre de 1792, que se vertebra en torno a la idea de la igualdad, consagrada expresamente como derecho fundamental y reforzada con el principio de solidaridad. En América, también Thomas Paine (1737-1809), en su conocida obra Rights of Man (1791), una respuesta a las críticas vertidas por Burke en sus «Reflexiones sobre la Revolución en Francia», y a partir de la constatación del incontrovertible hecho de que «a great portion of mankind, in what are called civilised countries, are in a state of poverty and wretchedness» ${ }^{20}$, esbozará un discurso en el que una idea moderna de la solidaridad estará claramente subyacente. «Civil Government — escribe Paine ${ }^{21}$ de modo harto significativo - does not exist in executions; but in making such provision for the instruction of youth and the support of age, as to exclude, as much as possible, profligacy from the one and despair from the other». Frente al criterio hedonístico, considerado por los liberales clásicos como el orientador exclusivo del homo oeconomicus, se producirá progresivamente lo que Menegazzi llamó «la rivoluzione dell’edonismo al solidarismo» ${ }^{22}$.

La cristalización definitiva del valor solidaridad y su influencia en la configuración de los fines y funciones de la sociedad civil y del Estado tendrá lugar a partir del siglo XIX. Este movimiento, continuación de la Ilustración con matices de romanticismo social, incorporará una dimensión laica y secularizada de la idea de solidaridad, que PecesBarba $^{23}$ identifica con la fraternidad de la trilogía revolucionaria y encuadra en el naciente Estado social de Derecho. La idea de la solidaridad se convirtió así en el punto focal de una mística social emergente que en la década que precede a la última de las grandes Revoluciones burguesas, la de 1848, llegó a ser abiertamente la defensora de una democracia socio-económica al igual que política ${ }^{24}$. Y junto a ella, íntimamente imbricada en ella, la idea de igualdad. Una y otra desempeñarán «un rôle moteur», como lo califica Béguin $^{25}$, en las diversas reivindicaciones sociales que encontrarán su expresión final en el Preámbulo de la Constitución francesa de la Cuarta República (1946).

Aunque ya los escritos del Conde de Saint-Simon (1760-1825) y su defensa de que la preocupación básica de la sociedad se centrara en la mejoría de los sectores más desfa-

19 Así, entre otros, DE LUCAS, J: «La polémica sobre los deberes...», op. cit., pág. 18, y PECES-BARBA, G: Curso de derechos..., op. cit., pág. 230.

20 PAINE, Th: Common Sense and Rights of Man (Bold-faced thoughts on revolution, reason, and personal freedom), edited by Laura Ross, Sterling Publishing, New York and London, 2011, pág. 429 (Rights of Man, en págs. 123 y ss).

21 Ibidem, págs. 439-440.

22 MENEGAZZI, G: I Fondamenti del Solidarismo, Giuffrè Editore, Milano, 1964, pág. 179.

23 PECES-BARBA MARTÍNEZ, G: Derecho y derechos fundamentales, Centro de Estudios Constitucionales, Madrid, 1993, pág. 145.

24 HAYWARD, J.E.S: «Solidarity: the Social History of an Idea...», op. cit., págs. 273-274.

25 BÉGUIN, J-C: «Service publique et solidarité», en La solidarité en droit public, textes réunis par JeanClaude Béguin, Patrick Charlot et Yan Laidié, L’Harmattan, Paris, págs. 253 y ss.; en concreto, pág. 262. 
vorecidos, y del socialista utópico Charles Fourier (1772-1837) y su crítica de la sociedad industrial, pueden considerarse precursores de esa preocupación por la solidaridad, hemos de hacer una particular mención de la posición sustentada por el político francés, líder del partido radical-demócrata, Léon Bourgeois (1851-1925), distinguido con el premio Nobel de la paz en 1920, quien, como recuerda Losano ${ }^{26}$, llevará el aspecto normativo de la solidaridad social hasta sus últimas consecuencias, ya que su teoría transforma la solidaridad en un derecho jurídicamente exigible. Con la publicación en 1896 de su libro «Solidarité», escribe Hayward ${ }^{27}$, «it would be accurate to assert of the notion of solidarity that it came, was seen and conquered». A comienzos del siglo XX esta línea de pensamiento solidarista, por así llamarla, tenía sus referentes en Bourgeois y Durkheim, aunque no podemos olvidar al ya mencionado Pierre Leroux, que parece haber sido el primero en usar el término «solidaridad» para las ciencias sociales, convirtiéndose, según lo caracteriza Losano ${ }^{28}$, en apóstol de una filosofía religiosa y civil del progreso social basada en el igualitarismo. Con la llegada del nuevo siglo, la idea de solidaridad se había convertido ya en Francia en lo que uno de sus defensores, Fouillée, llamó una ideafuerza, una idea de importancia clave que galvanizó, impulsó y dirigió la vida política, económica y social de la Francia del siglo XX.

En los primeros años del siglo XX, Duguit iba a transponer al ámbito del Derecho público la tesis durkheiniana de la división social del trabajo sustentada tan sólo tres años antes. A partir de una constatación pragmática absolutamente evidente, la de que «el hombre natural, aislado, nacido en condiciones de absoluta libertad e independencia respecto a los demás hombres, y en posesión de derechos fundados en esta misma libertad, en esta independencia misma, es una abstracción sin realidad alguna» ${ }^{29}$, el Decano de Burdeos iba a reformular la teoría del Estado y del Derecho en íntima conexión con la idea de la solidaridad, estableciendo, como recuerda la doctrina ${ }^{30}$, una estrecha relación entre solidaridad, servicio público y Estado.

El propio Duguit, en el tomo III de su célebre Traitể ${ }^{1}$, recuerda cómo en su libro «L État, le droit d'objectif et la loi positive», intentó mostrar que el fundamento del Derecho es la solidaridad o mutua interdependencia social, que todos los miembros de la sociedad están obligados por la norma jurídica a no hacer nada que sea contrario a la solidaridad social y, a la inversa, a hacer cuanto esté en su mano para asegurar la realización de los derechos que derivan de esa obligación que todo hombre tiene de cumplir su de-

26 LOSANO, M.G: «La cuestión social y el solidarismo francés: actualidad de una antigua doctrina», en la obra del que es editor el propio autor, Solidaridad y derechos humanos en tiempos de crisis, Editorial Dykinson/Instituto de Derechos Humanos Bartolomé de las Casas. Universidad Carlos III de Madrid, Madrid, 2011, págs. 15 y ss.; en concreto, pág. 23.

27 HAYWARD, J.E.S: «Solidarity: the Social History...», op. cit., pág. 280.

28 SOLANO, M.G: «Las teorías del solidarismo y su influencia en la formulación de los derechos fundamentales económicos», en Solidaridad y derechos humanos en tiempos de crisis, op. cit., págs. 37 y ss.; en concreto, pág. 39.

29 DUGUIT, L: Manual de Derecho Constitucional, traducción de José G. Acuña, $2^{\mathrm{a}}$ ed., Francisco Beltrán, Madrid, 1926, pág. 5.

30 BÉGUIN, J-C: «Service publique et solidarité», op. cit., pág. 254.

31 DUGUIT, L: Traité de Droit constitutionnel, tome troisième (La théorie générale de l'État), 3ème édition, E. de Boccard, Paris, 1930, págs. 640-641. 
ber social. «Je crois — concluye Duguit — avoir montré que le droit étant ainsi fondé sur la solidarité sociale s'impose aux détenteurs de la puissance politique, à l'État, qu'il en résulte pour lui l'obligation de ne faire aucune loi susceptible de porter atteinte au libre développement de l'activité individuelle, parce que ce libre développement est nécessaire pour que la solidarité sociale puisse se réaliser et se développer».

Más aún, la concepción que Duguit sostiene de la solidaridad conduce asimismo a la consecuencia de que el Estado se halla obligado a hacer determinadas leyes, a disponer de todo el poder de que dispone al servicio de la solidaridad social; consecuentemente, está forzado por el propio ordenamiento jurídico a elaborar cuantas leyes aseguren a cada uno la posibilidad material y moral de colaborar en la solidaridad social. En definitiva, para el Decano de Burdeos, la solidaridad, en cuanto mecanismo decisivo en el que sustentar la integración social, no sólo es el fundamento del Derecho en general, sino que es el elemento teleológico de la actividad estatal.

\section{EL PRINCIPIO DE SOLIDARIDAD EN EL ESTADO SOCIAL DE LA SEGUNDA POSTGUERRA}

I. Innecesario es decir por obvio que será el Estado de bienestar, el Welfare State, más comúnmente identificado entre nosotros como el Estado social, el que institucionalice la noción de la solidaridad. Fue Hermann Heller quien acuñó en 1903 la noción de «Estado social» (sozialer Rechtsstaat), con la que se iban a tratar de positivar viejas aspiraciones sociales, elevadas ahora a la categoría de principios constitucionales. Las Constituciones de Querétaro de 1917 y de Weimar de 1919 constituirán los primeros ejemplos significativos de esta nueva concepción del orden político. El nuevo modelo encontrará su momento álgido en el constitucionalismo de la segunda postguerra, en el que brillan con luz propia, en lo que ahora interesa, la Constitución francesa de la Cuarta República (1946), y la italiana de 1947. En relación con nuestro tema, nos limitaremos a aludir ellas de modo sumario.

La idea de bienestar, como bien apunta Añón ${ }^{32}$, conecta directamente con la de distribución o reparto de la riqueza social desde los presupuestos de los recursos disponibles y las cargas atribuibles. Y en el concepto de los welfare rights, uno de los rasgos más connotadores del Welfare State, vendrán a conjugarse el bienestar, los derechos sociales, las actuaciones prestacionales de los poderes públicos y la solidaridad, esto es, una multiplicidad de elementos estrechamente interconectados en los que se asienta el núcleo de una parte de las teorías sobre la ciudadanía, una ciudadanía activa, participativa y responsable, en lo que se ha visto como el punto de partida del que puede arrancar a su vez una justificación de la existencia de unos «deberes de solidaridad» ${ }^{33}$. En esta dirección doctrinal destacará notablemente Marshall, quien en un artículo («The Right to Welfare») inicialmente publicado en 1965, y tras considerar que el «bienestar» (welfare) es un com-

32 AÑÓN ROIG, M.J: Necesidades y derechos. Un ensayo de fundamentación, Centro de Estudios Constitucionales, Madrid, 1994, pág. 315.

33 Cfr. al respecto, DE LUCAS, J: «La polémica sobre los deberes de solidaridad», op . cit., en especial, págs. 24-26. 
puesto de medios materiales y fines inmateriales ${ }^{34}$, escribe: «(W)elfare is only to a very limited extent the product of social services or of social policy. Its roots lie deep in the social and economic system as a whole. Its realisation and enjoyment depend, therefore, on a number of other rights, (...) including those to property and personal freedom, to work and to justice» ${ }^{35}$. Innecesario es decir que la visión activa de la ciudadanía que subyace a esta concepción es plenamente compatible con el principio de solidaridad. El propio Marshall considerará que los grandes fines del Estado social son: la eliminación de la pobreza, la maximización del bienestar y la búsqueda de la igualdad, y ello se comprende a la perfección si se advierte que la pobreza, la marginación, la miseria y la exclusión no son fenómenos subjetivos, sino productos sociales ante los que el Estado no puede permanecer insensible, impertérrito. Estado prestacional y solidaridad caminan así de modo entrelazado.

II. El Preámbulo de la Constitución francesa de 27 de octubre de 1946 nos sitúa ante uno de los momentos estelares del Estado social, recurriendo ingeniosamente a una técnica original que conjuga, de un lado, la solemne reafirmación de los derechos y libertades del hombre y del ciudadano consagrados por la Declaración de Derechos de 1789 , a los que adiciona la novedosa categoría de los principios fundamentales reconocidos por las leyes de la República, y de otro, una serie de principios políticos, económicos y sociales que tilda de "particularmente necesarios a nuestro tiempo», y que procede a enumerar a continuación; entre ellos encontramos el principio de «la solidarité et l'égalité de tous les Français devant les charges qui résultent des calamités nationales». De esta forma, como dijera Vedel ${ }^{36}$, la atmósfera de liberalismo, y especialmente de liberalismo económico, con la que la Declaración de 1789 baña el Preámbulo, es contrapesada con una serie de nuevos principios fuertemente teñidos de socialismo y dirigismo. Como trasfondo de todo ello latían dos ideas tradicionalmente contrapuestas, aunque a partir de ahora interconectadas, de libertad: «liberté déjà donnée ou liberté à conquérir». Y como elemento subyacente al conjunto del Preámbulo, y en cierto modo dándole coherencia, latía una concepción humanista, asentada en la afirmación de la trascendencia del ser humano respecto de la sociedad.

Esta visión personalista reflejaba un sentir común del constitucionalismo social de la segunda postguerra, que, coherentemente con el postulado de que partía, la esencial dignidad intrínseca de todos los seres humanos ${ }^{37}$, y con la finalidad que perseguía, que no

34 MARSHALL, T.H: «The Right to Welfare», en la obra del propio autor, The Right to Welfare and other essays, Heinemann Educational Books, London, 1981, págs. 83 y ss.; en concreto, pág. 83.

35 Ibidem, pág. 93.

36 VEDEL, G: Droit constitutionnel, 2ème tirage (1er édition 1949), Sirey, Paris, 1984, págs. 327-328.

37 Recuerda Bognetti que la fórmula «human dignity» apareció por primera vez en trascendentes documentos internacionales, en particular la Declaración Universal de Derechos Humanos auspiciada por Naciones Unidas en 1948. Con posterioridad fue convertida en «the cornerstone» de la nueva Constitución alemana, la Grundgesetz, y también fue utilizada, aunque marginalmente, por la Constitución italiana. BOGNETTI, G: «The concept of human dignity in European and US constitutionalism», en Georg Nolte (editor), European and US Constitutionalism, Cambridge University Press, Cambridge, 2005, págs. 85 y ss.; en concreto, pág. 89. A su vez, Schambeck ha considerado que la dignidad humana y los derechos fundamentales a ella conexos no son tan sólo un mero objeto de conocimiento, sino también «a claim of conscience» que nadie que se considere como un ser humano libre y responsable puede negar, reconocimiento que, excediendo las fronteras estatales, se ha convertido en «a standard of humanity in law and politics» que puede alcanzarse en 
podía ser otra que posibilitar el desarrollo integral de la persona humana, se traducía en un plural conjunto de derechos en el que los llamados derechos de carácter económico y social, derechos prestacionales o welfare rights, habían de ocupar un muy relevante lugar, lo que casaba a la perfección con ese ideal de progreso de la civilización humana que subyace en el Welfare State, y que, como dijera Frosini ${ }^{38}$, se mide sobre todo en la ayuda dada por el más fuerte al más débil, en la limitación de los poderes naturales de aquél como reconocimiento de las exigencias morales de éste, en el aumento del sentido de una fraternidad humana sin la que los derechos a la libertad se convierten en privilegios egoístas y el principio de igualdad jurídica, en una nivelación basada en el sometimiento al poder del más fuerte.

En definitiva, bajo el rótulo de esos «principios particularmente necesarios a nuestro tiempo» latían verdaderos derechos socio-económicos de naturaleza en gran medida prestacional, lo que daría pie a Favoreu para apreciar muy pocas diferencias entre ellos y los que nuestra Constitución enmarca bajo el rótulo de "principios rectores de la política social y económica» ${ }^{39}$.

La instrumentalización jurídica por el Conseil constitutionnel del Preámbulo de la Carta de 1946, positivado asimismo por la Constitución de 1958, a través de la Decisión de 16 de julio de 1971 y de otras muchas posteriores, iba a contribuir decisivamente a extraer de los principios a que venimos aludiendo toda su potencialidad. Refiriéndonos tan sólo al principio de «solidaridad e igualdad de todos ante las cargas resultantes de las calamidades públicas» (párrafo duodécimo del Preámbulo), cabe recordar que fue contemplado por el juez constitucional en su Decisión 87-237 DC, de 30 de diciembre de 1987, Loi de finances 1988, en cuyo considerando 22 entendía que incumbe al legislador, cuando desarrolle el principio de solidaridad nacional, velar para que la diversidad de regímenes indemnizatorios instituidos no entrañe una quiebra del principio de igualdad de todos ante las cargas públicas. A su vez, en su Decisión 97-393 DC, de 18 de diciembre de 1997, Allocations familiales, (considerando 33), el Conseil constitutionnel fijó la doctrina de que la exigencia constitucional resultante de los párrafos décimo y undécimo del Preámbulo ${ }^{40}$ implica la puesta en práctica de una política de solidaridad nacional a favor de la familia, siéndole posible al legislador escoger las modalidades de ayuda a la familia que le parezcan apropiadas.

Digamos para terminar que aunque el Conseil constitutionnel, en muchos casos, ha puesto el acento en la competencia del legislador, y en ocasiones, también de la autoridad reglamentaria, para el desarrollo de los principios considerados por el Preámbulo como

Europa y, más allá de ella, en la entera comunidad de naciones. SCHAMBECK, H: «On human dignity in law and politics in Austria», en Filosofia dei Diritti Umani/Philosophy of Human Rights, Anno II, Fasc. 4-5, Napoli, Gennaio/Settembre 2000, págs. 19 y ss.; en concretro, pág. 26.

38 FROSINI, V: «Los derechos humanos en la sociedad tecnológica», en Anuario de Derechos Humanos (Universidad Complutense de Madrid), nº 2, 1983, págs. 101 y ss.; en concreto, pág. 107.

39 FAVOREU, L. en la obra suya y de RUBIO LLORENTE, F, El bloque de la constitucionalidad, Cuadernos Civitas/Universidad de Sevilla, Madrid, 1991, pág. 29.

40 El párrafo décimo establece el principio de aseguramiento por la nación al individuo y a la familia de las condiciones necesarias para su desarrollo. A su vez, el párrafo undécimo contempla la garantía de la protección de la salud y del derecho de todo ser humano incapacitado a obtener de la colectividad los medios necesarios para su existencia. 
«particulièrement nécessaires à notre temps», ello no ha venido a entrañar que el legislador pueda desarrollarlos a su arbitrio, sin fiscalización alguna. Bien al contrario, todos esos principios, y desde luego también el de solidaridad, han visto reconocido su valor constitucional, considerándolos el Conseil, en el ejercicio de su función de control de constitucionalidad de las leyes, oponibles frente al legislador, que se halla vinculado por ellos ${ }^{41}$.

III. La Constitución italiana de 1947 va a consagrar expresamente el principio de solidaridad en su art. $2^{\circ}$, a cuyo tenor: «La Repubblica riconosce e garantisce i diritti inviolabili dell'uomo, sia come singolo sia nelle formazioni sociali ove si svolge la sua personalità, e richiede l'adempimento dei doveri inderogabili di solidarietà politica, economica e sociale». La solidaridad, que, según Galeotti ${ }^{42}$, siempre existe como una cualidad obvia por sí misma en cualquier ordenamiento estatal, pues sin un mínimo de solidaridad ninguna sociedad existiría y estaríamos ante el bellum omnium contra omnes de hobbesiana memoria, es recepcionada en Italia como un valor jurídico-constitucional, y esa recepción se produce con una solemnidad y nitidez que no encuentra parangón en el constitucionalismo subsiguiente a la Segunda Guerra Mundial, constituyendo, como de nuevo escribe Galeotti ${ }^{43}$, la palabra emblemática de una especie de catecismo constitucional, equivalente en cierto modo a la francesa «fraternité» del trinomio revolucionario francés.

El art. $2^{\circ}$ encarna el principio fundamental que se ha denominado personalista, pues con su dicción, como advirtiera Mortati ${ }^{44}$, el precepto deja meridianamente claro que el hombre no está en función del Estado, sino que es el último quien se halla en función del primero, en el sentido de que su finalidad es asegurar el desarrollo de la persona humana y garantizar sus derechos. La norma habla de que «la República reconoce» esos «derechos inviolables», con lo que se viene a significar que no es el Estado quien los crea, sino que los encuentra radicados en la conciencia social, y ante ello se esfuerza en asegurar su respeto. $\mathrm{Y}$ a continuación el precepto relaciona esos «derechos inviolables» con unos «deberes inderogables de solidaridad». Con ello, los derechos asumen un cierto carácter funcional, en correspondencia con el fundamento ético sobre el que deben apoyarse, de modo tal que a través de su ejercicio pueda realizarse esa solidaridad social, que, como de nuevo dice Mortati ${ }^{45}$, es, a la par, presupuesto y resultado de un genuino régimen democrático. Y desde luego, la norma deja meridianamente clara que la solidaridad entraña la existencia de unos deberes, no sólo morales, sino también jurídicos, que parece lógico suponer que deben de ir más allá de la mera contribución económica al sosteni-

41 No es ajeno a todo ello que, desde la óptica del servicio público, y a partir del pensamiento de Duguit, Béguin haya escrito que lo que resta del mismo no es tanto que es el Estado el que justifica el servicio público, sino más bien que es el servicio público lo que legitima al propio Estado, operando, pues, esta exigencia de una actuación prestacional por parte de los poderes públicos como un auténtico principio de legitimidad, para, más adelante, concluir que el desarrollo de los servicios colectivos ha llegado a ser un medio de compromiso social y de reactivación del pacto republicano. BÉGUIN, J-C: «Service publique et solidarité», op. cit., págs. 256 y 261.

42 GALEOTTI, S: «Il valore della solidarietà», op. cit., pág. 4.

43 Ibidem, pág. 5.

44 MORTATI, C: Istituzioni di Diritto pubblico, tomo I, $10^{\mathrm{a}}$ ed. rielaborata ed aggiornata, a cura di Franco Modugno, Antonio Baldassarre e Carlo Mezzanotte, CEDAM, Padova, 1991, págs. 157-158.

45 Ibidem, pág. 159. 
miento de los gastos públicos, contribuyendo así a superar el que, no sin razón, se ha considerado ${ }^{46}$ uno de los riesgos más acusados en el proceso de construcción de la democracia y aun de la sociedad civil misma: la visión meramente pasiva de la ciudadanía. Por supuesto, a esa correlación entre derechos y deberes no ha de dársele un carácter absoluto. Es necesario distinguir dentro de esos deberes, los de contenido puramente negativo, que se agotan en el respeto del principio de no dañar la esfera propia de otros sujetos (alterum non laedere), de otros deberes vinculados a derechos que se reconocen a sus titulares para la satisfacción de intereses que, por su misma naturaleza trascienden la esfera propia de tales personas, en cuanto comprometen directamente intereses colectivos o generales, no pudiendo por lo mismo confiarse al mero criterio de la conveniencia de quien ejercita el derecho.

La norma transcrita halla su más profunda correspondencia con la conocida como cláusula Lelio Basso del párrafo segundo del art. $3^{\circ}$ de la propia Carta constitucional, que Barbera tilda de «formula della rivoluzione promessa» ${ }^{47}$, lo que encuentra su explicación en el hecho de que una norma como ésta desmiente todas aquellas afirmaciones de la Constitución que dan por realizado todo aquello que, sin embargo, aún está pendiente de alcanzarse (la igualdad, la libertad... etc.). Lelio Basso, el diputado constituyente italiano, a través de esta norma, no sólo estaba formulando un mandato para el legislador futuro, que debería elaborar aquella legislación necesaria para que la igualdad fuera realmente efectiva, sino que, a la par, como expone Romagnoli ${ }^{48}$, con tal norma estaba revelando la presencia en el mismo corazón del ordenamiento constitucional de una contradicción antagónica, hacia la que la propia dinámica generada por la norma estaba llamada a enfrentarse por medio de una transformación social regida por los valores materiales de la Constitución. La conocidísima cláusula, que encuentra su correlato en el art. $9^{\circ} .2$ de nuestra Constitución, viene a encomendar a la República la tarea de remover los obstáculos de orden económico y social que, limitando de hecho la libertad y la igualdad de los ciudadanos, impiden el pleno desarrollo de la persona humana y la efectiva participación de todos los trabajadores en la organización política, económica y social del país. También en este precepto emerge la persona humana como punto de referencia fundamental. El libre desarrollo de la misma — que también la Grundgesetz contempla bajo la dicción de la freie Entfaltung der Persönlichkeit, considerando ese libre desarrollo de la personalidad como un derecho de cada hombre (art. $2^{\circ} .1 \mathrm{GG}$ ) — en unión de la plena integración social de los ciudadanos, pues aunque la Constitución utiliza el término «lavoratori», bien puede entenderse esa referencia como hecha respecto de la totalidad de la ciudadanía, pues, como regla general, todo ciudadano es trabajador, constituyen los objetivos referenciales de cualquier actuación de los poderes públicos. Y de esta estrecha correspondencia puede extraerse que, en la medida en que sea posible una mayor apertura hacia nuevos espacios de libertad, ex art. $3^{\circ} .2$, podrán abrirse nuevos horizontes para una

46 DE LUCAS, J: «La polémica sobre los deberes de solidaridad», op. cit., pág. 13.

47 BARBERA, A: «Commentario dell'articolo 2», en Commentario della Costituzione, (Principi Fondamentali. Art. 1-12), a cura di Giuseppe Branca, Nicola Zanichelli Editore/Soc. Ed. del Foro Romano, Bologna/Roma, 1975, págs. 50 y ss.; en conctreto, pág. 58.

48 ROMAGNOLI, U: «Commentario dell'articolo 3, $2^{\circ}$ comma», en Commentario della Costituzione, (Principi Fondamentali. Art. 1-12), a cura di Giuseppe Branca, Nicola Zanichelli Editore/Soc. Ed. del Foro Italiano, Bologna/Roma, 1975, págs. 162 y ss.; en concreto, pág. 166. 
mayor afirmación de los deberes de solidaridad ${ }^{49}$. Por lo demás, la conexión entre la cláusula Lelio Basso y el art. $2^{\circ}$ nos muestra otra nueva virtualidad de la solidaridad, a la que alude Galeotti ${ }^{50}$ : el principio de solidaridad como motor de la función activa de la República, esto es, del conjunto de sus poderes públicos, empeñados en una función de promover solidariamente el desarrollo, quizá, a nuestro modo de ver, la más trascendental función que ha de cumplir el Estado social de nuestro tiempo.

Es cierto, sin embargo, que la aplicación práctica de la cláusula en cuestión ha sido decepcionante. Tras un cuarto de siglo de vida constitucional, Romagnoli parecía hacer suya la pesimista apreciación hecha unos años antes por Calamandrei, en el sentido de que, reducida al rango de pura y simple «raccomandazione di massima» durante largo tiempo, este precepto constitucional tan sólo había podido funcionar como «inspiración o pretexto» (spunto o appiglio) electoral para uno u otro partido político ${ }^{51}$. Más de una treintena de años después de la entrada en vigor de la Constitución, autor tan relevante como Lavagna ${ }^{52}$ consideraba que el principio de solidaridad no había desatado gran interés ni entre la doctrina ni en la jurisprudencia, probablemente por su carácter genérico, que parece a primera vista hacer de él «un dettato morale più che giuridico», un canon del que parece difícil, incluso para el legislador, hacer descender de cualquier modo «precisi obblighi e doveri», que no sean extraíbles de otras particulares disposiciones constitucionales.

En todo caso, ha de recordarse que la Corte Costituzionale ha tenido oportunidad de acudir en ocasiones al principio de solidaridad. Así, en su Sentencia 65/1979 ha considerado el deber de solidaridad como motivo inspirador de las garantías de prevención y asistencia social previstas por el art. 38 de la Constitución. Y en la Sentencia 92/1981, ha recurrido a la solidaridad como punto de apoyo constitucional para el resarcimiento de los daños de guerra.

IV. En Alemania, la Grundgesetz (GG) consagra en su art. 20.1 la cláusula del Estado social, que junto a la protección de la dignidad humana (art. $1^{\circ} .1$ GG), integran el núcleo del orden constitucional. Así parece corroborarlo el art. 79.3 de la propia GG, que impide la modificación, entre otros, de los principios establecidos en los artículos $1^{\circ}$ y 20.

En el debate político, como recuerda Benda ${ }^{53}$, la cláusula del Estado social es interpretada no como descripción de la conciencia del Estado contemporáneo, sino como programa que se debe realizar de cara al futuro. El Estado social no debe ser un mero papel sino hacerse realidad. Y así, todo progreso social deseable, especialmente cada demanda socialmente motivada y no cumplida, deberán ser interpretados como promesas de la Constitución a traducir en concreciones del Estado social de Derecho.

Aunque la Grundgesetz no consagra formalmente el principio de solidaridad, ésta puede verse implícitamente recepcionada en el art. 104a, cuando en su apartado cuarto

49 BARBERA, A: «Commentario dell'articolo 2», op. cit., pág. 97.

50 GALEOTTI, S: «Il valore della solidarietà», op. cit., pág. 14.

51 ROMAGNOLI, U: «Commentario dell’articolo 3, 2ºmma», op. cit., pág. 172.

52 LAVAGNA, C: «Su alcune direttrici costituzionali per la regolamentazione degli scioperi», en Giornale di Diritto del Lavoro e di Relazioni Industriali, Anno IV, nº 14, 1982, págs. 179 y ss.; en concreto, pág. 186.

53 BENDA, E: «El Estado social de Derecho», en Benda, Maihofer, Vogel, Hesse y Heyde, Manual de Derecho Constitucional, Instituto Vasco de Administración Pública/Marcial Pons, Ediciones Jurídicas y Sociales, Madrid, 1996, págs. 487 y ss.; en concreto, págs. 530-531. 
contempla la posibilidad de que la Federación conceda ayuda financiera a los Estados para inversiones especialmente importantes de éstos o de los Municipios que se consideren necesarias para prevenir una alteración del equilibrio económico nacional o para compensar disparidades de capacidad económica en el territorio federal. Asimismo, el art. 107.2 exige que a través de una ley se garantice que la capacidad financiera variable de los distintos Estados quede adecuadamente compensada. En fin, ubicándose en esta misma dirección, el art. 109.2 dispone que el Bund y los Länder tomen en consideración al formular sus presupuestos las exigencias del equilibrio económico general, y el propio artículo (en su apartado cuarto) prevé la posibilidad de adoptar diversas medidas encaminadas a prevenir cualquier perturbación del equilibrio económico general.

Como puede apreciarse, en ese objetivo insistentemente proclamado por la Grundgesetz, de alcanzar un equilibrio económico general entre los diferentes Länder, subyace implícitamente el principio de solidaridad.

V. En otros países europeos, el Estado social y con él el principio de solidaridad hicieron acto de presencia a través de otras vías. Mención especial merece al respecto el $\mathrm{Be}$ veridge Report inglés del año 194254. Escrito en 1942 por William Beveridge (18791963), un economista inglés influido por el socialismo fabiano, que dirigiera durante dieciocho años (1919-1937) la London School of Economics, y que a través de su propuesta buscaba la erradicación de los que denominaba los «Giant Evils»: la miseria, la enfermedad, la ignorancia, la desocupación y el ocio. Esos gigantescos males debían ser combatidos con la finalidad de proteger adecuadamente la salud y la instrucción, y el coste de tan enorme operación no debía recaer tan sólo en el Estado, sino que todos los ciudadanos debían contribuir con una aportación proporcional a su renta. La propuesta de Beveridge influyó decisivamente en la conformación del Estado social en Inglaterra hasta los años sesenta, encontrando la oportunidad de ser canalizada tras el triunfo de los laboristas de Clement Attlee en las elecciones de 1945.

En las antípodas se ha de situar a los Estados Unidos, cuyo sistema jurídico en el siglo XX seguía siendo la característica encarnación de la versión neo-liberal; aún así, recuerda Bognetti que la legislación federal creó sistemas de seguridad social y cuidado de la salud y reguló ciertos aspectos del régimen laboral, aun cuando esa regulación ofrecía tan sólo un mínimo nivel de protección para los valores sociales («social values») propios del Welfare State. Durante los años sesenta, la Warren Court (1953-1969), impactada por la crecida interdependencia de la vida americana, así como por la persistencia de la pobreza en gran cantidad de gente, se mostró proclive al reconocimiento de un derecho fundamental a, por lo menos, una asistencia gubernamental suficiente para satisfacer las necesidades más simples de la vida ${ }^{55}$. Sin embargo, la llegada a la Supreme Court de los Justices nombrados por el Presidente Nixon (Presidente entre 1969 y 1974) cambió el panorama, deteniendo el ímpetu que pareció impulsar en esta dirección a la Corte presidida por Warren. Así, la Burger Court (1969-1986) iba a declinar firmemente declarar la existencia de un derecho fundamental a la asistencia económica que fuera exigible judicialmente. Aunque los Justices reconocerían que sobre la autoridad gubernamental recaían

54 Cfr. al respecto, SOLANO, M.G: Solidaridad y derechos humanos en tiempos de crisis, op. cit., págs. 50-52.

55 En tal sentido, MURPHY, W.F: «An Ordering of Constitutional Values», en Southern California Law Review (S. Cal. L. Rev.), Vol. 53, 1979-1980, págs. 703 y ss.; en concreto, pág. 741. 
algunas restricciones procedimentales para retirar la asistencia social a los beneficiarios de la misma, la que bien podría considerarse como posición oficial de la Corte sobre esta cuestión era resumida por el Juez Byron R. White en el caso Lindsey v. Normet (1972), en el que el Tribunal apoyó una ley estatal que permitía el desahucio sumario de los arrendatarios con base en la siguiente consideración: «The Constitution does not provide judicial remedies for every social and economic ill (...). Absent constitutional mandate, the assurance of adequate housing and the definition of landlord-tenant relationships are legislative, not judicial functions ${ }^{56}$. En definitiva, la posición norteamericana en la cuestión que nos ocupa puede compendiarse en las siguientes palabras del Profesor Louis Henkin, de la Columbia University: "Welfare rights are legislative not constitutional, and are subject to political, ideological and budgetary restraints» ${ }^{57}$. Por otro lado, la Supreme Court ha rehusado interpretar la due process clause y la equal protection clause de un modo conducente a obligar a los Estados a proporcionar un umbral mínimo de servicios públicos. Los Estados son libres para ofrecer servicios sociales, si optan por hacerlo, como asimismo para precisar la medida de los mismos.

VI. Cabría añadir a todo lo expuesto, que la solidaridad ha encontrado un espacio en los principales instrumentos internacionales de protección de los derechos. Por poner un ejemplo, la Declaración Americana de los Derechos y Deberes del Hombre, aprobada en la Novena Conferencia Internacional Americana, celebrada en Bogotá en 1948, establece en su art. XII, relativo al derecho a la educación, que «toda persona tiene derecho a la educación, la que debe estar inspirada en los principios de libertad, moralidad y solidaridad humanas».

Un paso adelante en el progresivo protagonismo que en nuestra época viene alcanzando la idea de la solidaridad lo encontramos en la Carta de los Derechos Fundamentales de la Unión Europea del año 2000, que el Tratado de Lisboa, en vigor desde el $1^{\circ}$ de diciembre de 2009, incorpora con algunas modificaciones. En ella se dedica todo un capítulo, el cuarto, a la solidaridad, enunciándose dentro del mismo un conjunto de derechos relativos a la vida laboral, a la seguridad social, a la vida familiar y profesional, a la salud, al medio ambiente, a la protección de los consumidores... etc. Fue Vasak ${ }^{58}$ quien, por primera vez, aludió a los «derechos de solidaridad», terminología que justificaría en el hecho de que tales derechos traducen una cierta concepción de la vida en comunidad, no pudiendo realizarse más que por la conjunción de los esfuerzos de todos los participantes de la vida en sociedad: individuos, Estados y otras entidades públicas o privadas. Vasak pondría como específico ejemplos los derechos a un medio ambiente decente, al agua pura, al aire puro, e incluso el derecho a la paz.

Las disposiciones de la Carta Europea englobadas dentro del capítulo rotulado con el término de solidaridad, basadas sustancialmente en la Carta Social Europea y en la Carta Comunitaria de los Derechos Sociales Fundamentales de los Trabajadores, acogen gran parte de los derechos sociales, mientras algunos otros son recepcionados en el capítulo inmediato anterior, relativo a la igualdad. Esta ubicación sistemática no hace sino co-

56 Apud MURPHY, W.F. en Ibidem, pág. 742.

57 Apud GALEOTTI, S: «Il valore della solidarietà», op. cit., pág. 6.

58 VASAK, K: «Le droit international des droits de 1'homme», en Revue des droits de l'homme, Vol. 5/1, 1972, págs. 43 y ss.; en concreto, pág. 45. 
rroborar que la igualdad material y la solidaridad constituyen los dos reactores que impulsan al Estado social de nuestro tiempo.

La relevancia de la Carta se capta si se tiene en cuenta que la misma vincula a las instituciones de la Unión, al igual que a los Estados miembros cuando apliquen el Derecho de la Unión.

VII. Como se desprende de todo lo anterior, el principio de solidaridad se imbrica plenamente en el núcleo duro del Estado social. Es cierto que no todas las Constituciones de nuestro tiempo lo contemplan, aunque no lo es menos que en muchos casos ha de considerarse implícito en determinadas normas constitucionales, por lo que la ausencia de toda referencia al mismo no presupone ni mucho menos que el diseño constitucional se haya hecho de espaldas a tal principio. Su estrecha conexión con los derechos económicos, sociales y culturales así lo ha venido a corroborar, dada la amplitud con que los códigos constitucionales actuales recepcionan estos derechos de naturaleza básicamente prestacional. Piénsese al respecto en la estrecha vinculación entre la dimensión material de estos derechos, que se manifiesta en la pertinente prestación, su dimensión axiológica, que vendría encarnada en los valores de la igualdad y la justicia, y el propio valor de la solidaridad, sin olvidar un nuevo vínculo que pondría en conexión determinados derechos de la tercera o cuarta generación, según las distintas caracterizaciones doctrinales, con lo que se ha dado en llamar la solidaridad intergeneracional (el derecho a un medio ambiente adecuado al desarrollo de la persona sería quizá el ejemplo paradigmático). Como ha escrito Peces-Barba ${ }^{59}$, la solidaridad se integra con los demás valores, libertad, igualdad y (añadiríamos por nuestra cuenta) justicia, por el común objetivo de contribuir por medio de los derechos que fundamentan al dinamismo de la libertad, que a su vez facilita el ejercicio de la libertad de elección que a su vez conduce a la libertad o autonomía moral.

El Estado social, como es sobradamente conocido, rompe frontalmente con la visión individualista del Estado liberal, y de resultas de ello el ordenamiento constitucional adquiere una notable relevancia como articulador y constructor social ${ }^{60}$. En este marco, el principio de solidaridad va a coadyuvar en esa labor de mediación y articulación social.

Por otro lado, si de la solidaridad entre los individuos se pasa a la solidaridad interterritorial, el protagonismo de un principio como el que nos ocupa se acentúa, pues no en vano el mismo tiene que ver con la relación entre sí de los integrantes de un conjunto y con la relación del todo con cada una de sus partes. No ha de extrañar por lo mismo que el principio de solidaridad haya acentuado su presencia en algunos Estados compuestos, o lo que es igual, de estructura territorial compleja, como sería el caso de España.

En definitiva, en el Estado social de nuestros días la solidaridad, sin dejar de ser como es obvio un valor moral o una exigencia ética, ha sido recepcionada por los ordenamientos jurídicos de algunos Estados como un principio político al que se ha dotado de plena fuerza jurídica, con lo que de alguna manera ha adquirido el rol adicional de valor integrante del orden axiológico constitucional, en estrecha sintonía con el resto de valores superiores del ordenamiento jurídico. Ello justamente puede sostenerse de la recepción constitucional de la noción de solidaridad en nuestra Constitución.

59 Gregorio PECES-BARBA MARTÍNEZ, G: Curso de Derechos Fundamentales, I, op. cit., pág. 237.

60 DE CABO MARTÍN, C: Teoría constitucional de la solidaridad, Marcial Pons, Ediciones Jurídicas y Sociales, Madrid/Barcelona, 2006, pág. 67. 


\section{EL PRINCIPIO DE SOLIDARIDAD EN LA CONSTITUCIÓN DE 1978}

\section{A) Su recepción constitucional}

I. La Constitución de 1978 recepciona el principio de solidaridad en su art. $2^{\circ}$, cuya relevancia no es necesario poner de relieve, pero también alude a él de modo específico en otros preceptos constitucionales relacionados con el Estado autonómico. Se separa así de la Constitución italiana, no tanto porque nuestro constituyente haya sido más tímido que el transalpino a la hora de consagrar este principio, como podría quizá pensarse de una comparación entre el art. $2^{\circ}$ de una y otra norma fundamental, pues estamos de acuerdo con aquella doctrina ${ }^{61}$ que ha subrayado la forma rotunda y directa con que se recoge este principio en nuestra Constitución, sino porque en Italia la solidaridad aparece íntimamente imbricada con los derechos y deberes de los ciudadanos, mientras que en nuestro país se presenta estrechamente conectada con el diseño del Estado autonómico. Pareciera, pues, que mientras en Italia la solidaridad se vincula inextricablemente con el Estado social, en España ese vínculo lo asume con la organización territorial del Estado. Pero esta conclusión no dejaría de ser superficial e incluso quizá errónea. Y ello porque la solidaridad interterritorial no sólo no excluye, sino que presupone la solidaridad interpersonal, y además, porque la solidaridad entre las diferentes Comunidades Autónomas puede considerarse una manifestación más del Estado social. Como dijera el Tribunal Constitucional $^{62}$, la concepción del Estado como social y democrático de Derecho es un reflejo de la solidaridad e interrelación social, especialmente intensa en la época actual. Y a todo ello bien podría añadirse que la solidaridad se encuentra implícitamente acogida por determinados artículos de la parte dogmática de la Constitución, preceptos en cuya formulación anida con claridad meridiana la idea de solidaridad, y cuya vinculación con los postulados del Estado social es todavía más evidente. Es por ello por lo que, a continuación, nos referiremos separadamente a los preceptos en que se recepciona de modo expreso este principio y a aquellos otros en que puede atisbarse una recepción implícita del mismo.

II. Nuestra Norma suprema se refiere específicamente en varios de sus preceptos al principio de solidaridad:

a) En el art. $2^{\circ}$, la solidaridad aparece como un principio más, junto a los de unidad y autonomía, de la organización territorial del Estado, un principio que bien puede considerarse como de equilibrio entre la unidad y la autonomía ${ }^{63}$ - aunque no faltan quienes, aproximándolo en mayor medida al principio de unidad, lo han considerado sin más la otra cara del principio de autonomía ${ }^{64}$ — llamado a modular las inevitables tendencias

61 PÉREZ MORENO, A: «Solidaridad y Convenios entre Comunidades Autónomas», en Documentación Administrativa, $\mathrm{n}^{\circ} 181$, Enero/Marzo 1979, págs. 397 y ss.; en concreto, pág. 400

62 STC 62/1983, de 11 de julio, fund. jur. $2^{\circ}$, A), in fine.

63 Análoga es la interpretación del Tribunal Constitucional, para el que el principio de solidaridad no es, en definitiva, «sino un factor de equilibrio entre la autonomía de las nacionalidades o regiones, y la indisoluble unidad de la Nación española». STC 135/1992, de 5 de octubre, fund. jur. $7^{\circ}$, ab initio.

64 ENTRENA CUESTA, R: «Comentario al artículo 138», en Comentarios a la Constitución, dirigidos por Fernando Garrido Falla, $3^{a}$ ed., Civitas, Madrid, 2001, págs. 2406 y ss.; en concreto, pág. 2408. 
centrífugas y centrípetas que esos dos principios pueden generar, operando en último término, como dice Alonso de Antonio ${ }^{65}$, como un vínculo de unidad ${ }^{66}$, lo que explica que el art. 138.1 CE otorgue al Estado la garantía de su realización efectiva.

b) En el art. 138.1, como acabamos de decir, se encomienda específicamente al Estado la realización efectiva del principio de solidaridad. La búsqueda de efectividad de este principio, que, anticipémoslo ya, creemos que es también un valor, nos recuerda a la efectividad que el constituyente pretende asimismo dar a los valores de libertad e igualdad, de cuya efectividad responsabiliza (art. $9^{\circ} .2 \mathrm{CE}$ ) a todos los poderes públicos. Esa atribución al Estado de la garantía de la realización efectiva de la solidaridad entre las nacionalidades y regiones integrantes del Estado se traduce en una doble misión: de un lado, velar por el establecimiento de un equilibrio económico adecuado y justo entre las diversas partes del territorio, atendiendo al efecto a las peculiares circunstancias del hecho insular, y de otro, impedir que las diferencias estatutarias puedan implicar en algún caso privilegios económicos o sociales.

c) En el art. 156.1, se condiciona la autonomía financiera de que gozan las Comunidades Autónomas para la ejecución de sus competencias a que respeten, entre otros, el principio de solidaridad entre todos los españoles, operando de este modo el principio de solidaridad como un criterio de delimitación de dicha autonomía.

d) En fin, en el art. 158.2, se recurre a la solidaridad como criterio teleológico que justifica la existencia de un Fondo de Compensación destinado a gastos de inversión cuya finalidad última es corregir los desequilibrios económicos interterritoriales, dando efectividad así al principio de solidaridad.

III. Más allá de las específicas previsiones constitucionales que se refieren a la solidaridad, en el articulado constitucional hallamos otros preceptos en que este principio se halla implícito o subyacente. En buen número de casos tienen que ver con la enunciación de deberes constitucionales (en algún supuesto, incluso de derechos), aunque en otros se trata de mandatos dirigidos al legislador, o más ampliamente a los poderes públicos en general, o de normas de asignación de fines al Estado. Entre tales preceptos podemos recordar los siguientes:

a) El deber de defensa y, alternativamente, el deber de realizar una prestación social sustitutoria (art. 30.2 CE) sería el primer ejemplo de ello, que se complementaría con los deberes de la ciudadanía en situaciones excepcionales, como sería el caso de las catástrofes o calamidades públicas (art. 30.4), como asimismo con la posibilidad de establecer un servicio civil para el cumplimiento de fines de interés general (art. 30.3). Esta última previsión se estaría refiriendo a lo que se conoce como el «voluntariado», esto es, a la prestación de servicios asistenciales a la comunidad, pues eso es lo que parece indicar la fórmula elegida por el constituyente, «fines de interés general» ${ }^{67}$.

65 ALONSO DE ANTONIO, J.A: El Estado autonómico y el principio de solidaridad como colaboración legislativa, vol. I, Congreso de los Diputados, Madrid, 1986, pág. 377.

66 Para Santolaya el principio de solidaridad está concebido como una forma dinámica de realización de la unidad del Estado a partir de la autonomía. SANTOLAYA MACHETTI, P: Descentralización y cooperación (Introducción al estudio de los mecanismos de cooperación en los Estados basados en la descentralización política; su aplicación al caso español), Instituto de Estudios de Administración Local, Madrid, 1984, pág. 299.

67 En sentido análogo, DE LUCAS, J: «La polémica sobre los deberes de solidaridad», op. cit., pág. 60. 
b) El deber de contribuir al sostenimiento de los gastos públicos de acuerdo con la respectiva capacidad económica y mediante un sistema tributario justo inspirado en los principios de igualdad y progresividad (art. 31.1 CE), como es patente, presenta una obvia dimensión solidaria, pues es el principio de solidaridad el que fundamenta tal nor$\mathrm{ma}^{68}$, en cuanto que la misma, con meridiana claridad, puede contribuir a propiciar una más justa redistribución de la riqueza, objetivo que no sólo debe inspirar la potestad de planeamiento por parte del Estado (art. 131.1 CE), sino que, innecesario es decirlo, camina parejo con el que podría considerarse como el horizonte teleológico del principio de solidaridad. En su art. 31.1 nuestra Constitución, a diferencia de otras, alude expresamente al principio de la capacidad contributiva y, además, como constatara el Tribunal Constitucional $^{69}$, lo hace sin agotar en ella el principio de justicia en materia contributiva, pues nuestro constituyente ha dejado bien claro que el sistema justo que se proclama no puede separarse, en ningún caso, del principio de progresividad ${ }^{70}$ ni del principio de igualdad. A partir de estos principios de justicia tributaria, el Tribunal Constitucional ha venido a considerar ${ }^{71}$ el impuesto sobre la renta de las personas físicas como, «tal vez, el instrumento más idóneo para alcanzar los objetivos de redistribución de la renta (art. 131.1 CE) y de solidaridad (art. 138.1 CE), que la Constitución española propugna y que dotan de contenido al Estado social y democrático de Derecho (art. $\left.1^{\circ} .1 \mathrm{CE}\right){ }^{72}$.

c) El reconocimiento de la función social de los derechos a la propiedad privada y a la herencia (art. 33.2 CE), es un fiel reflejo del principio solidario, pues es patente que frente a las posiciones economicistas, a las que ya tuvimos oportunidad de referirnos, que

68 En sentido semejante se pronuncia entre nosotros DE LUCAS, J, en «La polémica sobre los deberes de solidaridad», op. cit., pág. 44. Y en relación al ordenamiento brasileño, similar es la posición de Carrazza, quien escribe al respecto que «os impostos, quando ajustados à capacidade contributiva, permitem que os cidadâos cumpram, perante a comunidade, seus deveres de solidariedade política, econômica e social». (Roque Antônio CARRAZZA: Curso de Direito constitucional tributário, 19ª ed., Malheiros Editores, Sâo Paulo, 2003, pág. 78). No toda la doctrina comparte esta postura. Y así, Falcón y Tella cree que, técnicamente, el principio de solidaridad debe desligarse de otros preceptos y principios con un contenido similar, de carácter redistributivo, como el principio de capacidad contributiva. (Ramón FALCÓN Y TELLA: La compensación financiera interterritorial, Congreso de los Diputados, Madrid, 1986, pág. 303). Análogamente, Vidal Gil cree que es cuando menos dudoso que el art. 31 establezca un deber de solidaridad (Ernesto J. VIDAL GIL: «Sobre los derechos de solidaridad...», op. cit., pág. 109).

69 STC 27/1981, de 20 de julio, fund. jur. $4^{\circ}$.

70 Conviene recordar que es doctrina del Tribunal Constitucional, que la progresividad no es exigible de cada tributo en particular, sino del sistema tributario en su conjunto. Consiguientemente, el Tribunal admite que en un sistema tributario justo pueden tener cabida tributos que no sean progresivos, siempre que no se vea afectada la progresividad del sistema, pues en la indispensable desigualdad cualitativa que se realiza mediante la progresividad global del sistema tributario alienta la aspiración a la redistribución de la renta (y con ello, añadiríamos por nuestra cuenta, al objetivo de la solidaridad). STC 7/2010, de 27 de abril, fund. jur. $6^{\circ}$, entre otras varias en la misma dirección.

71 STC 137/2003, de 3 de julio, fund. jur. $7^{\circ}$. «Es innegable — razona el Alto Tribunal— que el impuesto sobre la renta de las personas físicas, por su carácter general y personal, y figura central de la imposición directa, constituye una de las piezas básicas de nuestro sistema tributario, siendo el tributo en el que el principio de capacidad económica y su correlato, el de igualdad y progresividad tributarias, encuentran una más cabal proyección, de manera que es, tal vez, el instrumento más idóneo para alcanzar los objetivos de redistribución de la renta (art. 131.1 CE) y de solidaridad (art. 138.1 CE) que la Constitución propugna y que dotan de contenido al Estado social y democrático de Derecho».

72 Esta doctrina sería reiterada en sus propios términos en la STC 189/2005, de 7 de julio, fund. jur. $8^{\circ}$. 
siempre han puesto el acento en el poder de dominio del propietario sobre el bien objeto del mismo, acoge una visión que atiende al interés general y que, por lo mismo, en último término, recepciona un principio de solidaridad.

d) La dimensión solidaria late asimismo en diversas normas del Capítulo $3^{\circ}$ del Título I. Tal es el caso del mandato dirigido a todos los poderes públicos de mantener un régimen público de Seguridad Social para todos los ciudadanos, que garantice la asistencia y prestaciones sociales suficientes ante situaciones de necesidad, especialmente en caso de desempleo (art. $41 \mathrm{CE}$ ). La misma filosofía preside el reconocimiento del derecho a la protección de la salud, con la subsiguiente obligación que recae sobre los poderes públicos de tutelar la salud pública a través, entre otras diversas actuaciones, de las prestaciones y servicios necesarios (art. $43 \mathrm{CE}$ ). Y otro tanto se puede decir de la encomienda a los poderes públicos de la garantía, mediante pensiones adecuadas y periódicamente actualizadas, de la suficiencia económica de los ciudadanos durante la tercera edad (art. 50 CE). Justamente, al hilo de lo que ha de entenderse por «pensión adecuada», el Tribunal Constitucional tuvo oportunidad de manifestarse acerca de una de las exigencias del principio de solidaridad.

En las cuestiones de inconstitucionalidad desencadenantes de la STC 134/1987, se hallaba en cuestión la conformidad con tal concepto de la fijación de un tope máximo para las pensiones y la no actualización de las superiores a ese tope. El Tribunal, con evidente razón a nuestro juicio, consideraba que el concepto de "pensión adecuada» no podía considerarse aisladamente, atendiendo a cada pensión singular, sino que debía tener en cuenta el sistema de pensiones en su conjunto, sin que pueda prescindirse de las circunstancias sociales y económicas de cada momento, y sin que quepa olvidar que se trata de administrar medios económicos limitados para un gran número de necesidades sociales. De ahí que al fijar un límite a la percepción de nuevas pensiones o al negar la actualización durante un tiempo de las que superan ese límite, a juicio del Tribunal ${ }^{73}$, el legislador no rebasa el ámbito de las funciones que le corresponden en la apreciación de aquellas circunstancias socioeconómicas que condicionan la adecuación y actualización del sistema de pensiones, pues esa valoración no puede prescindir del deber de solidaridad entre todos los ciudadanos, «una de cuyas exigencias esenciales es, precisamente, el sacrificio de los intereses de los más favorecidos frente a los más desamparados con independencia, incluso, de las consecuencias puramente económicas de esos sacrificios ${ }^{74}$.

e) El reconocimiento del derecho de todos a disfrutar de un medio ambiente adecuado para el desarrollo de la persona, así como del deber que sobre todos pesa de conservarlo (art. 45.1 CE) se enmarca con absoluta claridad en esa solidaridad intergeneracional a la que en un momento anterior tuvimos oportunidad de referirnos. Más aún, cuando el art. 45.2 CE encomienda a los poderes públicos que velen por la utilización racional de todos los recursos naturales, con el fin de proteger y mejorar la calidad de vida y defender y restaurar el medio ambiente, precisa que en tal actuación se apoyarán en la «indispensable solidaridad colectiva», conformando así un auténtico deber ciudadano en relación al respeto y adecuada conservación de los recursos naturales. Bien podría pues de-

73 STC 134/1987, de 21 de julio, fund. jur. $5^{\circ}$.

74 El Tribunal reiteraría esta doctrina, en sus mismos términos, en la STC 100/1990, de 30 de mayo, fund. jur. $2^{\circ}$. 
cirse, que al mandato que recae sobre los poderes públicos, de proteger ese bien constitucional que es el medio ambiente ${ }^{75}$, se sobrepone un deber colectivo de respetarlo, que recae sobre la totalidad de la ciudadanía, y que de modo inequívoco puede considerarse como un deber de solidaridad.

f) La solidaridad se descubre $\operatorname{también}^{76}$ en la idea de equilibrio regional que se encuentra presente en el art. 40.1 CE, que postula una distribución más equitativa de la renta regional y personal, y asimismo en el art. 131.1 CE, que habilita al Estado para llevar a cabo el planeamiento de la actividad económica general con diversos objetivos, entre ellos, el de equilibrar y armonizar el desarrollo regional y sectorial. El propio Tribunal Constitucional ha podido sostener ${ }^{77}$, que la determinación contenida en el art. 40.1 CE puede considerarse como una plasmación especial del principio constitucional de solidaridad.

g) Incluso el propio deber de instruirse, que puede considerarse implícito en la obligatoriedad de la enseñanza básica (art. 27.4 CE), y el deber de trabajar, que innecesario es decir que se trata también de un derecho (art. 35.1 CE), no dejan de presentarse conexos con las obligaciones que pueden hacerse dimanar de la solidaridad. Así lo admitiría sin atisbo de duda, en relación a Italia, Carlo Lavagna ${ }^{78}$, y creemos que aunque nuestra Constitución, a diferencia de la italiana, no aluda de modo expreso a los deberes de solidaridad, ello no es óbice para admitirlos y para sustentar una visión abierta de tales deberes.

No faltan desde luego objeciones abundantes frente a la noción de «deberes de solidaridad», que se reconducen en lo básico a argumentos técnicos. No podemos ocuparnos aquí del tema ${ }^{79}$, aunque sí recordaremos, entre otros argumentos contrarios, el de que no cabe aceptar deberes allí donde falta la nota lógica de la reciprocidad con los derechos, o el de que la solidaridad, como cualquier otra virtud, no puede imponerse y por ello resultaría ajena al Derecho. A la primera objeción habría que responder que no falta un beneficiario del cumplimiento de tales deberes: la colectividad, y que la justificación de los mismos no puede visualizarse en el Estado social de nuestro tiempo desde la lógica iusprivatista tradicional. Ciertamente, desde una perspectiva muy amplia, podría decirse con Ferrajoli, que el Welfare State no ha desarrollado una normatividad propia, no ha producido una estructura institucional de garantías análoga a la del viejo Estado liberal de Derecho y específicamente idónea para garantizar los nuevos derechos sociales correspondientes a las nuevas funciones y prestaciones exigibles del Estado ${ }^{80}$. El resultado de estas carencias, la consecuencia de esta convivencia entre el viejo Estado constitucio-

75 El Tribunal Constitucional, como no podía ser de otro modo, ha admitido que dentro del marco de la política global del medio ambiente y del respeto al principio de solidaridad son constitucionalmente posibles una diversidad de regulaciones, una concurrencia de actuaciones estatales y autonómicas, en este último caso no sólo de ejecución sino de «desarrollo legislativo» de la legislación básica y de imposición de «medidas adicionales de protección». STC 64/1982, de 4 de noviembre, fund. jur. $4^{\circ}$, in fine.

76 En igual sentido, BAÑO LEÓN, J.M: Las autonomías territoriales y el principio de uniformidad de las condiciones de vida, Instituto Nacional de Administración Pública, Madrid, 1988, pág. 181.

77 STC 146/1992, de 16 de octubre, fund. jur. $1^{\circ}$.

78 LAVAGNA, C: «Su alcune direttrici costituzionali...», op. cit., pág. 186.

79 Nos remitimos al respecto a DE LUCAS, J: «La polémica sobre los deberes de solidaridad», op. cit., págs. 36-41.

80 FERRAJOLI, L: «Stato Sociale e Stato de Diritto», en Politica del Diritto, Anno XIII, n 1, Marzo 1982, págs. 41 y ss.; en concreto, pág. 42. 
nal de Derecho y el nuevo Estado social es una profunda divergencia entre las estructuras legales y las estructuras reales tanto de la organización estatal como de la propia organización social. Y desde una óptica más estricta, podría vislumbrarse en la mencionada objeción una lógica similar a la utilizada para negar la vigencia de los derechos fundamentales en las relaciones inter privatos. Como entre nosotros argumenta Vidal Gil ${ }^{81}$, la estructura heredada del Derecho civil y del paradigma del Derecho privado, que presupone la igual condición de las partes y somete sus relaciones jurídicas a la reciprocidad y correlatividad en la atribución de derechos y deberes es inadecuada para contemplar los deberes del Estado que se traducen en actuaciones positivas, y, en su caso, los deberes de los propios ciudadanos.

Y en cuanto a la segunda objeción, ya hemos tenido oportunidad de señalar que una vez que la solidaridad ha sido constitucionalizada como principio jurídico-político, que a la par creemos que opera como un valor integrado en la galaxia del orden axiológico constitucional, ha adquirido plena fuerza normativa y, por lo mismo, vincula con carácter general. El Tribunal Constitucional ha tenido a este respecto oportunidad de afirmar, en relación a los principios de igualdad material y solidaridad (y ya es bien significativo que se refiera a ellos conjuntamente), que aunque «no suponen por sí mismos la atribución de competencia a las Comunidades Autónomas», es evidente «que tales principios vinculan a todos los poderes públicos, en el ejercicio de sus respectivas competencias, y no sólo al Estado» ${ }^{82}$. Y aunque como es doctrina constitucional bien conocida ${ }^{83}$, la sujeción a la Constitución, que a todos obliga (art. $9^{\circ} .1 \mathrm{CE}$ ), se traduce en un deber de distinto signo para los ciudadanos y los poderes públicos, pues mientras sobre los titulares de los poderes públicos pesa no sólo un deber general negativo de abstenerse de cualquier actuación que vulnere la Constitución, sino también un deber general positivo de realizar sus funciones de acuerdo con la Constitución, sobre los ciudadanos, como regla general, recae tan sólo aquel deber negativo, sin perjuicio, claro está, de los supuestos en que la Constitución establece deberes positivos, es evidente que, tal y como se acaba de exponer, determinados artículos de la Constitución contemplan deberes que pueden hacerse vinculantes, si es que no lo son de inmediato, a través de la mediación del legislador, deberes que bien podrían reconducirse a la genérica categoría de los «deberes de solidaridad».

IV. Al margen ya de los derechos o deberes mencionados, que bien podríamos tildar, en sintonía con lo que hace la Carta de Derechos Fundamentales de la Unión Europea, como «derechos (y deberes) de solidaridad», no nos cabe duda de que la solidaridad subyace en otros principios constitucionales, como sería el caso del de igualdad material, en la medida en que también expresa un criterio material de justicia redistributiva ${ }^{84}$. Un en-

81 VIDAL GIL, E.J: «Sobre los derechos de solidaridad...», op. cit., págs. 103-104.

82 STC 150/1990, de 4 de octubre, fund. jur. 11.

83 STC 101/1983, de 18 de noviembre, fund. jur. $3^{\circ}$.

84 No podemos entrar aquí en detalle en la interesantísima cuestión que se ha planteado Dworkin, acerca de la fórmula idónea de distribución de la igualdad. (Cfr. al respecto, DWORKIN, R: «What Is Equality? Part 1: Equality of Welfare», en Philosophy \& Public Affairs, Princeton University Press, Vol. 10, No. 3, Summer, 1981, págs. 185 y ss.). Con todo, nos parece de interés hacer alguna reflexión al respecto. A partir de la consideración de que «(e)quality is a popular but mysterious political idea», pues «(p)eople can become equal (or at least more equal) in one way with the consequence that they become unequal (or more unequal) in 
tendimiento de la igualdad en sentido material, se ha escrito ${ }^{85}$, constituye la medida o idea-fuerza de la solidaridad. No se trata, desde luego, de que la solidaridad pretenda alcanzar la uniformidad entre todos los ciudadanos, sino tan sólo de conseguir un cierto equilibrio entre ellos, un minimum de armonía en sus condiciones de vida. Ya hemos tenido oportunidad de poner de relieve que la recepción constitucional de un principio como el de solidaridad no es tanto la resultante de la pretensión de positivar un valor ético o moral, cuanto el deseo de recepcionar en el código constitucional un valor íntimamente conexo con la igualdad y la justicia, valores estos últimos que el art. $1^{\circ} .1 \mathrm{CE}$ eleva a la categoría de «valores superiores» del ordenamiento jurídico.

No albergamos la más mínima duda de que nuestra Constitución, al igual que otros textos europeos, parte de un principio personalista, que toma al ser humano como verdadero prius, como punto de partida y de referencia. "Civitas homini, non homo civitati existit», podríamos afirmar, retomando el viejo aforismo romano. La proclamación como fundamento del orden político de la dignidad de la persona, de los derechos inviolables que le son inherentes y del libre desarrollo de la personalidad (art. 10.1 CE) no deja resquicio alguno a la duda. Piénsese además en que el libre desarrollo de la personalidad no es sino la manifestación personalizada de la dignidad intrínseca de todos los seres humanos, que se manifiesta en la libre capacidad de autodeterminación de cada persona. De su trascendencia para el ordenamiento constitucional puede dar buena idea el hecho de que el art. 27.2 CE disponga que la educación tendrá por objeto el pleno desarrollo de la personalidad humana. Este principio personalista, que toma como valor fundamental de referencia a la persona humana, emerge asimismo en el art. $9^{\circ} .2 \mathrm{CE}$ — cuya conexión con el 10.1 nos parece indiscutible - fiel trasunto, como ya dijimos, de la cláusula Lelio Basso, donde no sólo se rompe de modo frontal con la tradicional concepción de los derechos en el constitucionalismo liberal como derechos negativos, recepcionándose una visión del Estado que otorga prestaciones (Leistungsstaat), concepto comprensivo en el ámbito de la Administración pública, como ha recordado la doctrina ${ }^{86}$, de lo que Forsthoff denominara la «procura existencial» (Daseinsvorsorge), sino que en él se está tomando el libre desarrollo de la persona y su plena integración social como objetivos primigenios. Y es a tal efecto

others» (p. 185), Dworkin toma en consideración dos teorías generales acerca de la distribución de la igualdad, que denomina: equality of welfare y equality of resources (p. 186). Dworkin recuerda (p. 188) que el concepto de «welfare» fue inventado o por lo menos adoptado por los economistas precisamente para describir lo que es fundamental en la vida más bien que lo que es meramente instrumental, y a partir de ahí el relevante autor entiende el principio de igualdad de bienestar en el sentido de que, en la medida de lo posible, nadie debería tener menos bienestar que los demás ( «so far as is possible, no one should have less welfare than anyone else») (p. 191). En cuanto a la «equality of resources», se traduce en que todos los ciudadanos dispongan de los mismos recursos, a cuyo efecto se han de corregir los hándicaps naturales (p. 186). Dworkin se decanta por la fórmula de la equality of resources. «Equality of welfare —escribe (p. 244) — is not so coherent or attractive an ideal as it often taken to be». Como entre nosotros ha significado Añón, Dworkin descarta la fórmula de la igualdad de bienestar porque la identifica con el principio de igual satisfacción, mientras que él es partidario de una distribución del bienestar como principio y no como meta, decantándose por lo tanto por la equality of resources, en cuanto esta fórmula atiende no sólo a los bienes a repartir sino también a las capacidades y condiciones de las personas. (María José AÑÓN ROIG: Necesidades y derechos. Un ensayo de fundamentación, Centro de Estudios Constitucionales, Madrid, 1994, pág. 299).

85 PÉREZ MORENO, A: «Solidaridad y Convenios...», op. cit., pág. 402.

86 BAÑO LEÓN, J.M: Las autonomías territoriales y el principio de uniformidad de las condiciones de vida, op. cit., pág. 176. 
por lo que se encomienda a los poderes públicos que promuevan las condiciones y que remuevan los obstáculos que impidan o dificulten la plenitud del libre desarrollo de la persona en todos los ámbitos de su existencia y su participación en todos los ámbitos de la vida social.

Este mandato dirigido a la totalidad de los poderes públicos tendrá su correlato en los principios rectores del capítulo $3^{\circ}$ del Título I, muchos de los cuales tienden a otorgar a la ciudadanía un status básico en su vida social ${ }^{87}$, obligando en bastantes casos a los poderes públicos a ofrecer a los ciudadanos, a través de una organización adecuada, la prestación de determinados servicios orientados a la satisfacción de necesidades sociales básicas. Por lo mismo, bien podría decirse que los principios rectores de la política social y económica refuerzan la imagen del hombre condensada en el art. 10.1. Y por otro lado, vienen a sancionar, como ha escrito Hesse, una cierta condición irrevocable del Estado social, ya que a ningún gobierno cabe hoy en día incumplir las tareas de procura, previsión y compensación sociales ${ }^{88}$.

A la vista de lo que se acaba de decir, no creemos que pueda existir mucha duda acerca de que la dimensión central de la noción de solidaridad en el Estado social, que, como señala Peces-Barba ${ }^{89}$, es la idea de una función promocional del poder a través del Derecho, queda reflejada primigeniamente en el art. $9^{\circ} .2$, vinculándose así estrechamente con el principio personalista, que, como antes dijimos, también emerge en este último precepto. También en Italia, cuyo ordenamiento constitucional, en este ámbito material, sirvió como punto de referencia inmediato a nuestro constituyente, Galeotti ha destaca$\mathrm{do}^{90}$ que el valor de la solidaridad está íntimamente vinculado al principio personalista, y como tal puede considerarse como principio fundante de la Constitución democrática italiana.

De todo lo expuesto creemos que puede extraerse una conclusión última. La solidaridad, aun cuando no se halle expresamente proclamada dentro del orden axiológico constitucional, constituye un valor superior del ordenamiento jurídico. En nada obsta a ello el silencio constitucional, pues como con evidente razón aduce Peces-Barba ${ }^{91}$, cuando el art. $1^{\circ} .1 \mathrm{CE}$ establece la tétrada valorativa que todos conocemos, no enuncia un orden cerrado de valores, un numerus clausus, que impida que otros, como la solidaridad, pueda entrar en ese ámbito axiológico. Nuestra Constitución nos ofrece suficientes referencias explícitas a la solidaridad, complementadas, como se ha visto, por otra serie de referencias normativas en las que la misma puede vislumbrarse implícitamente - $\sin$ ir más lejos la misma caracterización del Estado como social, que presupone un Estado prestacional cuya razón de ser última ha de verse en la solidaridad, corolario del principio personalista en que todo el orden político se asienta - como para que no alberguemos

87 En sentido análogo se pronuncia BAÑO LEÓN, en Ibidem.

88 Apud LÓPEZ PINA, A: «De los principios rectores de la política social y económica» (Comentario al Capítulo III del Título I), en Comentarios a la Constitución Española de 1978, dirigidos por Oscar Alzaga Villaamil, Cortes Generales/Editoriales de Derecho Reunidas, tomo IV, Madrid, 1996, págs. 17 y ss.; en concreto, pág. 25.

89 PECES-BARBA MARTÍNEZ, G: Derecho y derechos fundamentales, Centro de Estudios Constitucionales, Madrid, 1993, pág. 127.

90 GALEOTTI, S: «Il valore della solidarietà», op. cit., pág. 10.

91 PECES-BARBA MARTÍNEZ, G: Derecho y derechos fundamentales, op. cit., págs. 171-172. 
dudas acerca de la ubicación de la solidaridad entre los valores superiores a los que se refiere el art. $1^{\circ} .1 \mathrm{CE}$. Por lo demás, es ésta una posición mayoritariamente acogida por la doctrina que se ha preocupado del tema ${ }^{92}$, y también Jiménez de Parga, actuando como Presidente del Tribunal Constitucional, en un voto particular, hizo suya tal concepción, considerando que «la solidaridad, como principio constitucional y expresamente constitucionalizado, es uno de los fundamentos del ordenamiento jurídico-político, a partir del cual se despliega un aparato de normas» ${ }^{93}$.

\section{B) El alcance de la solidaridad interterritorial}

a) El carácter polisémico de la solidaridad y su recepción como principio general de organización por el art. $2^{\circ} \mathrm{CE}$

I. El alcance que ha de darse al principio de solidaridad en su formulación constitucional exige de modo inexcusable atender con cierto detenimiento a las previsiones constitucionales, pues el concepto, por sí mismo, es de difícil delimitación dada su naturaleza polisémica. Como ha puesto de relieve la doctrina ${ }^{94}$, incluso en el mundo jurídico, la solidaridad ofrece la suficiente porosidad como para provocar su incognoscibilidad, ya que es capaz de contener los más diversos sentidos. Otro sector doctrinal ha acudido a la noción de los conceptos jurídicos indeterminados llegado el momento de pronunciarse sobre el contenido jurídico del principio de solidaridad, lo que justifican

92 Para García Roca, el que la solidaridad no se mencione entre los valores «superiores» del ordenamiento jurídico que enuncia el art. $1^{\circ}$. 1 CE no impide su caracterización como valor — sea superior o no- en otros preceptos constitucionales, dados sus contenidos claramente axiológicos. GARCÍA ROCA, J: «Asimetrías autonómicas y principio constitucional de solidaridad», en Revista Vasca de Administración Pública, $\mathrm{n}^{\circ} 47$ (II), Enero/Abril 1997, págs. 45 y ss.; en concreto, pág. 69. En el mismo sentido se había manifestado ya unos años antes el propio autor, en «La solidaridad autonómica, valor del ordenamiento», en Revista de la Facultad de Derecho de la Universidad Complutense, $\mathrm{n}^{\circ} 70$, Invierno 1983, págs. 251 y ss. Montero Rodríguez considera la solidaridad como uno de los valores más esenciales de nuestra Constitución, tal vez el que más debe contribuir a dotarla de sentido y asegurar su buen funcionamiento. Sin la solidaridad, añadirá este autor, es inconcebible que prevalezcan en convivencia pacífica la libertad, la justicia, la igualdad y el pluralismo político, propugnados como «valores superiores de nuestro ordenamiento jurídico». (Celso MONTERO RODRÍGUEZ: «La solidaridad constitucional y sus problemas en el Estado autonómico», en Jornadas de Estudio sobre el Título Preliminar de la Constitución, (Dirección General del Servicio Jurídico del Estado), Vol. II, Ministerio de Justicia, Madrid, 1988, págs. 1241 y ss.; en concreto, pág. 1243. Peces-Barba, como es obvio tras la posición que de él hemos expuesto, incluye la solidaridad entre los que denomina «valores relacionales», que son los que se refieren a los sujetos y a las formas de vida social, a los comportamientos, entre ellos, que favorezcan desde esa dimensión de las relaciones entre las personas la realización de los ideales de libertad y de igualdad que conducen a la libertad moral o autonomía moral. (PECES-BARBA MARTÍNEZ, G: Derecho y derechos fundamentales, op. cit., pág. 319). En fin, DE LUCAS, J (en «La polémica sobre los deberes...», op. cit., pág. 48) hace suya en su totalidad esta tesis de Peces-Barba.

93 STC 14/2004, de 12 de febrero, Voto particular que formula el Presidente, don Manuel Jiménez de Parga y Cabrera, punto $2^{\circ}$. Añade Jiménez de Parga más adelante, que «la solidaridad es uno de los soportes estructurales del ordenamiento constitucional, uno de los fundamentos de la distribución y orden de las partes importantes del edificio jurídico-político».

94 ORLANDO SORTO, F: «La compleja noción de solidaridad como valor y como Derecho: la conducta de Brasil en relación a ciertos Estados menos favorecidos», en Mario G. Solano (ed.), Solidaridad y derechos bumanos en tiempos de crisis, op. cit., págs. 97 y ss.; en concreto, pág. 119. 
por su carácter relativo e historicista, expuesto a mutaciones con el devenir del tiempo ${ }^{95}$, lo que a su vez se traduce en la necesidad de integración, especificación y concreción del principio. Atenderemos pues, más adelante, con algún detalle, al contenido de las distintas determinaciones en las que el constituyente se ha hecho eco del principio que nos ocupa, que en lo básico tienen que ver con la solidaridad interregional, aun cuando conviene recordar que el principio de solidaridad se mueve en distintos planos ${ }^{96}$.

II. El iter constituyente no arroja muchos cambios en la redacción del art. $2^{\circ}$ de la Constitución, pues la norma quedó definitivamente redactada en la Comisión del Congreso. Sin embargo, es de interés recordar la primitiva redacción que se dio al artículo en el Anteproyecto Constitucional (publicado, como es de sobra conocido, en el «Boletín Oficial de las Cortes» del 5 de enero de 1978). En él, la norma quedaba redactada así: «La Constitución se fundamenta en la unidad de España y la solidaridad entre sus pueblos y reconoce el derecho a la autonomía de las nacionalidades y regiones que la integran». Como fácilmente puede apreciarse, el principio de solidaridad presentaba en ese texto primigenio un carácter fundante análogo al del principio de unidad, del que se prescindiría en la redacción definitiva, no obstante lo cual, como parece por entero lógico, es muy común la interpretación que conecta íntimamente la unidad y la solidaridad, y en armonía con ello sitúa a la última como el contrapunto del principio de autonomía.

El art. $2^{\circ}$ establece un principio general de organización del Estado. A través del reconocimiento de un derecho a la autonomía de las nacionalidades y regiones integrantes de la Nación española, España se estructura en una nueva forma de Estado: el Estado autonómico. La Constitución no sólo reconoce y garantiza ese derecho a la autonomía de las nacionalidades y regiones, sino también la solidaridad entre todas ellas. La solidaridad se convierte así en un principio de articulación de los intereses generales y los particulares, y por lo mismo, en un mecanismo de conexión profunda entre las partes (las Comunidades Autónomas) y el todo (el Estado) ${ }^{97}$ en el que se integran. Ante la inevitable tensión entre el impulso centrípeto de la unidad y la fuerza centrífuga de la autonomía, la soli-

95 Posiblemente, la primera toma de postura en tal sentido correspondiera a PÉREZ MORENO, A (en «Técnicas jurídicas garantizadoras del principio de solidaridad regional», en Estudios sobre el Proyecto de Constitución, Centro de Estudios Constitucionales, Madrid, 1978, págs. 703 y ss.; en concreto, pág. 710). Poco tiempo después, el propio autor (en «Solidaridad y Convenios entre Comunidades Autónomas», op. cit., pág. 403) insistiría en su idea, que también haría suya Alonso de Antonio (ALONSO DE ANTONIO, J.A: El Estado autonómico y el principio de solidaridad..., op. cit., Vol. I, pág. 378).

96 Alonso de Antonio, desde la vertiente territorial, diferencia un cuádruple plano: solidaridad de las Comunidades Autónomas con el Estado, solidaridad de éste con aquéllas, solidaridad entre las Comunidades Autónomas y, en fin, solidaridad en el interior de cada Comunidad Autónoma. La amplitud de esta visión tiene que ver con la amplitud de manifestaciones de la solidaridad visualizadas por este autor. (ALONSO DE ANTONIO, J.A: El Estado autonómico y el principio de solidaridad..., op. cit., pág. 380). Falcón, atendiendo a los preceptos constitucionales, distingue a su vez un triple ámbito de la solidaridad: la solidaridad interpersonal, que ve reflejada en los arts. 45.2 y 156.1; la solidaridad interterritorial, a la que se refieren los arts. 2, 138 y 158.2, y la solidaridad intersectorial, que aparece implícitamente recogida en los arts. 40.1 y 131. (FALCÓN Y TELLA, R: La compensación financiera interterritorial, op. cit., págs. 116 y ss.). En fin, Pérez Moreno considera que la solidaridad se manifiesta en tres dimensiones: solidaridad entre las Comunidades Autónomas y el Estado, solidaridad intrarregional y la que considera como la dimensión básica, la solidaridad interregional. (PÉREZ MORENO, A: «Solidaridad y Convenios entre Comunidades Autónomas», op. cit., págs. 404 y 406).

97 ALONSO DE ANTONIO, J.A: «El principio de solidaridad en el Estado autonómico. Sus manifestaciones jurídicas», en Revista de Derecho Político, n 21 , Primavera 1984, págs. 31 y ss.; en concreto, pág. 80. 
daridad se nos presenta como un elemento de cohesión. Como antes dijimos, en el tratamiento que a la solidaridad da el art. $2^{\circ} \mathrm{CE}$ se ha visto una clave de unidad del nuevo Estado, a modo de contrapunto a la autonomía de las regiones ${ }^{98}$. El propio Tribunal Constitucional ha llegado a tildar el principio de solidaridad como el «corolario» del derecho a la autonomía ${ }^{99}$. Bien podría añadirse a todo lo expuesto, que este principio viene a corresponsabilizar a todas las partes del conjunto en los objetivos de la colectividad.

En sintonía con la amplia operatividad que de la solidaridad posibilita su enunciación por el art. $2^{\circ} \mathrm{CE}$, compartimos por entero la apreciación del «intérprete supremo de la Constitución» en el sentido de que el principio de solidaridad «requiere que, en el ejercicio de sus competencias (las Comunidades Autónomas) se abstengan de adoptar decisiones o realizar actos que perjudiquen o perturben el interés general y tengan, por el contrario, en cuenta la comunidad de intereses que las vincula entre sí y que no puede resultar disgregada o menoscabada a consecuencia de una gestión insolidaria de los propios intereses» ${ }^{100}$. Dicho de otro modo, cuando una Comunidad ejercita sus competencias no sólo debe atender a su propio interés, sino que también ha de ponderar las consecuencias que de dicho ejercicio puedan derivarse para las demás, evitando los efectos perjudiciales para los restantes entes territoriales afectados por sus medidas. La autonomía no se garantiza constitucionalmente para incidir de forma negativa sobre los intereses generales de la nación o sobre intereses generales distintos de los de la propia entidad. Y el principio de solidaridad, como ya hemos dicho y también ha admitido el Alto Tribunal, puede actuar como una suerte de corolario del de autonomía.

Podría, en definitiva, con una orientación de amplio espectro, sostenida por un sector de la doctrina alemana, verse en el principio de solidaridad una suerte de cláusula general (Generalklausel) que exige atender, tener en cuenta, el interés común, y no sólo el propio, en el ejercicio por los entes territoriales de sus respectivas competencias ${ }^{101}$.

b) El contenido fundamentalmente económico del principio de solidaridad

I. Omisión hecha del art. 45.2 CE, al que ya nos hemos referido, que alude a una solidaridad colectiva en relación a la utilización racional de todos los recursos naturales, el resto de preceptos constitucionales que se hacen eco del principio de solidaridad se encuentran en el Título VIII, relativo a la organización territorial del Estado. A ellos pasamos a referirnos.

A) Quizá de todos los preceptos sea el art. 138 el más trascendente, pues es en él donde con más nitidez va a fijar el constituyente el significado primigenio de este principio. En su apartado primero, el precepto encomienda al Estado la realización efectiva

98 LÓPEZ NIETO, A y FERNÁNDEZ RODRÍGUEZ, F: «La solidaridad y el desarrollo regional en la Constitución y en la LOFCA», en La España de las Autonomías. Pasado, presente y futuro, Espasa-Calpe, Madrid, 1981, tomo II, págs. 187 y ss.; en concreto, pág. 208.

99 STC 25/1981, de 14 de julio, fund. jur. $3^{\circ}$. Asimismo, en la STC 64/1990, de 5 de abril, fund. jur. $7^{\circ}$, in fine.

100 STC 64/1990, de 5 de abril, fund. jur. $7^{\circ}$. Asimismo, STC 247/2007, de 12 de diciembre, fund. jur. 20 .

101 En sentido análogo, Ramón FALCÓN Y TELLA: La compensación financiera interterritorial, op. cit., pág. 133.

UNED. Teoría y Realidad Constitucional, núm. 30, 2012, pp. 139-181. 
del principio de solidaridad consagrado en el art. $2^{\circ}$, y tras ello establece el primero de los dos contenidos de la solidaridad, al precisar que el Estado debe velar por «el establecimiento de un equilibrio económico adecuado y justo entre las diversas partes del territorio español», particularizando de inmediato que el Estado habrá de atender en particular a las circunstancias del hecho insular. Esta determinación, con claridad meridiana, anuda a la solidaridad la idea de equilibrio económico. Se ha subrayado ${ }^{102}$ el hecho de que el artículo en cuestión huya de la expresión igualdad interregional como meta de la solidaridad, decantándose por el término equilibrio, aunque en modo alguno debe extrañar que así sea, pues, a nuestro entender, si con carácter general la igualdad no puede entenderse como pretensión de uniformidad, mucho menos se puede tratar de conseguir tal uniformidad a través de la noción de la solidaridad. Con ella lo que se va a pretender de modo primario es la corrección de los desequilibrios interterritoriales.

El art. 138.1 debe necesariamente ponerse en conexión con otros dos preceptos, a los que ya hemos aludido. En primer término, con el art. 131.1, que habilita al Estado, mediante ley, para planificar la actividad económica general, y ello, entre otros fines, con el objetivo de equilibrar y armonizar el desarrollo regional. Y en segundo lugar, con el art. 40.1, que encomienda a los poderes públicos el promover las condiciones favorables para el progreso social y económico y, lo que más importa ahora, para una distribución de la renta regional y personal más equitativa. Particularmente llamativa es la fundamental coincidencia que se puede constatar entre el contenido que se da a la solidaridad en el art. 138.1 y los objetivos a que, a tenor del art. 131.1, debe responder la planificación de la actividad económica general. Ello se traduce en dos consecuencias significativas: de un lado, la solidaridad vincula el ejercicio de la potestad de planeamiento porque es una finalidad que el plan debe perseguir, y de otro, es también la justificación última de la misma existencia de aquella potestad. Por consiguiente, como escribe Muñoz Machado ${ }^{103}$, técnicamente el principio de solidaridad opera aquí como hecho habilitante y fin de la potestad, lo que, como es lógico, permite emplearlo como criterio para el control de su ejercicio.

Por lo demás, así entendida, la solidaridad tiene un alcance eminentemente económico, algo en lo que coincide la generalidad de la doctrina ${ }^{104}$, aunque algún autor ${ }^{105}$ matice que se trata de un contenido estrictamente financiero ${ }^{106}$. En cualquier caso, que el

102 DE JUAN PEÑALOSA, J.L: «El principio de solidaridad interregional...», op. cit., pág. 204.

103 MUÑOZ MACHADO, S: Derecho Público de las Comunidades Autónomas, $2^{\mathrm{a}}$ ed., Iustel, Madrid, 2007, tomo I, pág. 216.

104 Es el caso, por poner tan sólo un ejemplo de LUCAS VERDÚ, P y LUCAS MURILLO DE LA CUEVA, P en «La solidaridad interterritorial» (Comentario al Artículo 138), en Comentarios a la Constitución Española de 1978, dirigidos por Oscar Alzaga Villaamil, tomo X, Cortes Generales/Editoriales de Derecho Reunidas, Madrid, 1998, págs. 459 y ss.; en concreto, pág. 462.

105 FALCÓN Y TELLA, R: La compensación financiera interterritorial, op. cit., pág. 303. La solidaridad tiene, a juicio de este autor, un contenido básico que es estrictamente financiero: la compensación (Finanzausgleich) horizontal entre las Comunidades Autónomas. A ello se referiría el art. 138.1, quedando al margen la compensación vertical (entre el Estado y las Comunidades Autónomas), que, en cambio, no sería una manifestación del principio de solidaridad, sino exclusivamente de los principios de autonomía y suficiencia.

106 En alguna ocasión, también el Tribunal Constitucional ha admitido que el contenido más importante del principio de solidaridad es el financiero. Así, en la STC 135/1992, de 5 de octubre, fund. jur. $7^{\circ}$. 
contenido de la solidaridad sea, en lo básico, económico no impide que este principio pueda ponerse en conexión con otros mecanismos, desplegando otros efectos, pero sobre ello volveremos más adelante.

El apartado primero del art. 138 no agota el contenido del principio, que ha de complementarse con la previsión del apartado segundo, que consagra lo que podríamos llamar la interdicción de todo privilegio. A tenor del mismo: «Las diferencias entre los Estatutos de las distintas Comunidades Autónomas no podrán implicar, en ningún caso, privilegios económicos o sociales». Con ello, se reconoce con toda rotundidad que el ejercicio del derecho a la autonomía no puede entrañar ningún trato discriminatorio entre ciudadanos de Comunidades Autónomas diferentes. No deja de ser bien significativo que el apartado primero del precepto inmediato posterior proclame que «todos los españoles tienen los mismos derechos y obligaciones en cualquier parte del territorio del Estado» (art. 139.1). Y para asegurar que este precepto encuentre adecuado desarrollo, el art. 149.1, $1^{\text {a }} \mathrm{CE}$ atribuye al Estado la competencia exclusiva sobre «la regulación de las condiciones básicas que garanticen la igualdad de todos los españoles en el ejercicio de los derechos y en el cumplimiento de los deberes constitucionales». Innecesario es decir que un régimen estatutario de privilegio no sólo vulneraría el principio de solidaridad, sino que conculcaría asimismo el principio de igualdad y, con ello, también la previsión del art. 139.1 CE.

B) También el art. 156.1, que reconoce el principio de autonomía financiera de las Comunidades Autónomas "para el desarrollo y ejecución de sus competencias», se refiere a la solidaridad al contemplar los principios que han de regir el ejercicio de esa autonomía financiera, que no son sino el de coordinación con la Hacienda estatal y el de solidaridad entre todos los españoles. El precepto sitúa a la solidaridad como un criterio rector que ha de inspirar la autonomía financiera de las Comunidades Autónomas y, a la par, como un límite material de la misma. Innecesario es advertir acerca de la trascendencia de la financiación autonómica con vistas a alcanzar un cierto equilibrio interterritorial. Que la norma que consagra la autonomía financiera de las Comunidades Autónomas haya acogido como criterio rector de tal financiación al principio de solidaridad no puede sino interpretarse, como señala Baño León ${ }^{107}$, como la clara expresión de que la financiación autonómica también debe cumplir un cometido armonizador de las estructuras económicas públicas regionales.

La autonomía financiera de las Comunidades, correlato imprescindible de su autonomía política, debe pues partir de la consideración de los dos principios mencionados por el art. 156.1, al margen ya de atender a la competencia que al Estado reconoce el art. 149.1.14 CE en materia de «hacienda general», y como ha entendido ${ }^{108}$ el Tribunal Constitucional, dado que en la determinación de la participación de cada Comunidad Autónoma en los ingresos del Estado están en juego la suficiencia de todas las Comunidades Autónomas, su autonomía financiera y la solidaridad entre todas ellas (y, en último término, la suficiencia financiera del Estado y la de todo el sector público), es evidente la necesidad de que en este ámbito se adopte la decisión correspondiente de forma coordi-

107 BAÑO LEÓN, J.M: Las autonomías territoriales y el principio de uniformidad..., op. cit., págs. 180-181.

108 STC $13 / 2007$, de 18 de enero, fund. jur. $8^{\circ}$. 
nada entre el Estado y las Comunidades Autónomas en el seno de un órgano en el que estén representados todas éstas y aquél, órgano que no es otro que el Consejo de Política Fiscal y Financiera de las Comunidades Autónomas, al que se refiere el art. $3^{\circ} .1$ LOFCA, cuya naturaleza es la propia de un órgano consultivo y deliberante.

La afirmación en el ámbito fiscal del principio de solidaridad no debe presuponer que su realización exija la uniformidad impositiva ni mucho menos el centralismo en la gerencia de los recursos tributarios, esto es, en la exacción o en el gasto, aunque parece claro que la singularidad impositiva no debe terminar conduciendo a un régimen privilegiado que posibilite que el esfuerzo fiscal en situaciones comparables sea menor para unos que para otros. En último término, la necesaria armonización entre el pluralismo fiscal y la solidaridad será una cuestión de medida y ponderación, como bien razona De Juan $^{109}$.

C) El principio de solidaridad encuentra su última manifestación en el art. 158.2, que, justamente para corregir los desequilibrios interterritoriales y hacer efectivo el principio de solidaridad, prevé la constitución de un Fondo de Compensación con destino a gastos de inversión, cuyos recursos serán distribuidos por las Cortes Generales entre las Comunidades Autónomas a través del procedimiento específico que se contempla en el art. 74.2 CE, uno de cuyos rasgos más peculiares es la iniciación del procedimiento en el Senado, aunque, caso de desacuerdo entre las dos Cámaras no resuelto por la decisión que al efecto pueda adoptar la Comisión mixta paritaria que en tal caso ha de constituirse, será el Congreso quien habrá de decidir por la mayoría absoluta de sus miembros, previsión que aunque casa con la función minimalista atribuida constitucionalmente al Senado, no nos parece en exceso afortunada.

El Fondo de Compensación Interterritorial se convierte así en la expresión más directa y específica del principio de solidaridad, viniendo a operar como un elemento de articulación del sistema de financiación autonómica con los principios de solidaridad y redistribución de renta y riqueza, algo que se ha de entender indispensable para la propia armonía del sistema autonómico.

El desarrollo legal del art. 158.2 CE se llevó a cabo por el art. 16 LOFCA (Ley Orgánica 8/1980, de 22 de septiembre, de Financiación de las Comunidades Autónomas) y, con mayor detalle, por la Ley del Fondo de Compensación Interterritorial ${ }^{110}$. Hasta su segunda regulación por la Ley 29/1990, el Fondo era no sólo un instrumento redistributivo, sino que se concebía también como elemento de suficiencia financiera ${ }^{111}$; así, los recursos del Fondo, además de tener por objetivo el desarrollo de los territorios más desfavorecidos, atendieron simultáneamente las necesidades de gasto en inversiones nuevas de los servicios traspasados por el Estado; de ahí que fueran beneficiarias del mismo todas las Comunidades Autónomas. El mencionado texto legal iba a alterar de modo sustancial la situación, delimitando el Fondo como instrumento de desarrollo regional

109 Cfr. al respecto DE JUAN PEÑALOSA, J.L: «El principio de solidaridad interregional...», op. cit., págs. 193-195.

110 La primera ley reguladora del Fondo fue la Ley 7/1984, de 31 de marzo, posteriormente derogada por la Ley 29/1990, de 26 de diciembre, que a su vez sería derogada por la Ley 22/2001, de 27 de diciembre, reguladora de los Fondos de Compensación Interterritorial.

111 PEMÁN GAVÍN, J: Igualdad de los ciudadanos y autonomías territoriales, Editorial Civitas/Prensas Universitarias. Universidad de Zaragoza, Madrid, Zaragoza/Madrid, 1992, pág. 274. 
destinado exclusivamente a hacer efectivo el principio de solidaridad y exonerándolo de su vinculación a la financiación de los servicios traspasados por el Estado. En coherencia con ello, las Comunidades Autónomas perceptoras de los recursos del Fondo iban a ser únicamente las de menor desarrollo económico dentro del Estado, determinándose los territorios beneficiarios del nuevo Fondo consecuentemente con la práctica adoptada por la Comunidad Económica Europea de aquel entonces para determinar las regiones beneficiarias del FEDER (Fondo Europeo de Desarrollo Regional). Finalmente, la Ley 22/2001, reguladora de los Fondos de Compensación Interterritorial, iba a crear dos Fondos distintos: el Fondo de Compensación y el Fondo Complementario, lo que era la resultante del Acuerdo del Consejo de Política Fiscal y Financiera de 27 de julio de 2001, por el que se aprobaba el sistema de financiación de las Comunidades Autónomas de régimen común. El Consejo aprobó la propuesta consistente en que el Fondo pudiera financiar no sólo gastos de inversión, sino también los gastos corrientes asociados a esa inversión. Dado que el art. 158.2 CE dispone que el Fondo se destinará a gastos de inversión, se optó por separar el antiguo Fondo de Compensación Interterritorial en dos Fondos: el Fondo de Compensación, que se ciñe estrictamente al mandato constitucional, y el Fondo Complementario, que puede financiar la puesta en marcha o en funcionamiento de inversiones, hasta un máximo de dos años. Como se afirma en la Exposición de Motivos de la Ley 22/2001, esta división del antiguo Fondo no obsta para que los dos Fondos que se crean deban ser considerados, por su naturaleza, destino y gestión, como partes íntimamente ligadas de un único instrumento de financiación de las Comunidades Autónomas, vinculado a aquellos proyectos de inversión que promuevan el crecimiento de la renta y de la riqueza de sus habitantes.

En resumen, desde una óptica estrictamente constitucional, nos hallamos en presencia de un instrumento de compensación ordinaria destinado íntegramente a gastos de inversión, cuyos recursos configuró la Ley Orgánica 8/1980, de Financiación de las Comunidades Autónomas (LOFCA) como carga general del Estado, por lo que, hoy, los dos Fondos antes mencionados se nutren de los Presupuestos Generales del Estado, que han de dotarlos anualmente, y no de aportaciones de las Comunidades Autónomas con mayor nivel de riqueza.

Desde una perspectiva comparada, y a la vista de los modelos foráneos de nivelación territorial del gasto público, generalmente preocupados por igualar, equiparar o aproximar la capacidad fiscal per capita de los entes territoriales, o los índices de prestación de los servicios públicos, se ha subrayado ${ }^{112}$ la especificidad del modelo constitucional español, que se separa con nitidez de esos otros modelos foráneos, pues en la opción entre la equiparación fiscal (esto es, la aproximación de la capacidad fiscal de los entes territoriales) y la corrección de los desequilibrios económicos interterritoriales, se opta por la segunda opción niveladora. Dicho de otro modo, la corrección de tales desequilibrios económicos entre las Comunidades Autónomas se va a perseguir a través de gastos de inversión pública, que se superponen al resto de la inversión pública. Esta divergencia ha sido, sin embargo, matizada por Falcón ${ }^{113}$, recordando que el objetivo de equiparación fis-

112 LÓPEZ NIETO, A y FERNÁNDEZ RODRÍGUEZ, F: «La solidaridad y el desarrollo regional en la Constitución y en la LOFCA», op. cit., pág. 194.

113 FALCÓN Y TELLA, R: La compensación financiera interterritorial, op. cit., pág. 116. 
cal también se halla presente en el ordenamiento español, de modo específico, en la participación en ingresos del Estado y en las asignaciones que para las Comunidades Autónomas contempla el art. 158.1 CE, que se han de fijar en función del volumen de los servicios y actividades estatales que hayan asumido y de la garantía de un nivel mínimo en la prestación de los servicios públicos fundamentales en todo el territorio español. Es bastante clara, desde luego, la diferenciación que el propio texto constitucional hace entre lo que se ha dado en denominar la consecución del principio de igualdad esencial ${ }^{114}$, que vendría dado por la equiparación en los niveles de prestación de servicios públicos fundamentales (art. 158.1) 115 $^{11}$ y la corrección de los desequilibrios económicos (art. 158.2), que puede considerarse como la plasmación en el campo económico del principio de solidaridad, pero justamente por ello, parece bastante claro que la solidaridad se trata de operativizar a través específicamente de la corrección de los desequilibrios económicos.

Los Fondos de Compensación y Complementario, parece claro después de todo lo expuesto, son los principales instrumentos encaminados a efectivizar el principio de solidaridad, en ese ideal que formula la Constitución de equilibrio económico o de desarrollo regional equilibrado ${ }^{116}$, pero parece también obvio, que la solidaridad no se agota en tales instrumentos.

II. Examinadas las previsiones en las que la Constitución se hace eco de modo explícito del principio de solidaridad, se puede llegar con facilidad a la conclusión ya señalada de que las mismas tienen un alcance esencial, aunque no exclusivamente, económico. Es perfectamente comprensible que sea así, pues la constitucionalización del principio de solidaridad no se hará en el vacío, sino en un contexto caracterizado por acentuadas diferencias económicas territoriales; la solidaridad será, pues, la respuesta del constituyente frente a ese desequilibrio que se pretende corregir. De esta forma, la solidaridad se trata de encauzar a través de una serie de mecanismos encaminados a asegurar una más justa distribución territorial de la riqueza, intentando por intermedio de los mismos corregir los seculares desequilibrios regionales ${ }^{117}$ o, en términos de Baño

114 ENTRENA CUESTA, R: "Comentario al Artículo 158», en Comentarios a la Constitución, dirigidos por Fernando Garrido Falla, $3^{a}$ ed., Civitas, Madrid, 2001, págs. 2643 y ss.; en concreto, págs. 2644-2645. El principio de igualdad esencial, a juicio de este autor, comporta una doble exigencia: en primer lugar, la adecuación entre los medios de las Comunidades Autónomas y el volumen de servicios y actividades estatales que hayan asumido. Y en segundo lugar, la garantía de un nivel mínimo en la prestación de los servicios públicos fundamentales en todo el territorio español.

115 En cumplimiento del art. 158.1 CE, el art. 15.2 LOFCA contempla un Fondo de Garantía de Servicios Públicos Fundamentales, que tendrá por objeto garantizar que cada Comunidad recibe, en los términos fijados por la ley, los mismos recursos por habitante, ajustados en función de sus necesidades diferenciales, para financiar los servicios públicos fundamentales, garantizando la cobertura del nivel mínimo de los servicios fundamentales en todo el territorio. Cabe añadir que en la constitución de este Fondo participan las Comunidades Autónomas con un porcentaje de sus tributos cedidos, en términos normativos, y el Estado con su aportación, en los porcentajes y cuantías que marque la Ley.

116 PEMÁN GAVÍN, J: Igualdad de los ciudadanos y autonomías territoriales, op. cit., pág. 304.

117 Es esta una idea en la que, por razones de su propia obviedad, encontramos una amplia convergencia doctrinal. Así, por ejemplo, ALONSO DE ANTONIO, J.A: El Estado autonómico y el principio de solidaridad..., op. cit., Vol. I, pág. 380. Análogamente, DE JUAN Y PEÑALOSA, J.L: «El principio de solidaridad interregional...», op. cit., pág. 204. Y también Antonio JIMÉNEZ-BLANCO: Las relaciones de funcionamiento entre el poder central y los entes territoriales (Supervisión, solidaridad, coordinación), Instituto de Estudios de Administración Local, Madrid, 1985, pág. 246. 
León ${ }^{118}$, lograr la uniformidad de las condiciones de vida en todo el territorio nacional. Cohesión, equilibrio, armonía en las relaciones económicas y en las condiciones de vida de la ciudadanía, tales son las metas a alcanzar a través de la solidaridad.

Las previsiones constitucionales relativas a la solidaridad tienen un cierto impacto sobre el ejercicio de sus respectivas competencias por las Comunidades Autónomas, pero también por el Estado, y en ello existe una cierta communis opinio entre la doctrina ${ }^{119}$. Ante todo, es claro que la obligación que al Estado impone el art. 138.1 de garantizar la realización efectiva del principio de solidaridad, velando al efecto por el establecimiento de un equilibrio entre las distintas partes de nuestro territorio, justifica la atribución de potestades al Estado, (aunque, anticipémoslo ya, el principio de solidaridad en sí mismo considerado no opera como fuente atributiva de competencias al Estado) al margen ya de que ese objetivo de efectivizar el principio de solidaridad se convierta en guía o criterio básico de actuación (en los términos de algún otro autor, criterio condicionante) en el ejercicio de sus competencias. Particular relevancia presenta como criterio vinculante llegado el momento de que el Estado ejerza su potestad de planeamiento ex art. 131. Junto a ello, el principio de solidaridad se traduce manifiestamente en un límite en el ejercicio de las competencias autonómicas. Pero de todo ello nos ocupamos con mayor detalle a continuación.

\section{c) Otros posibles alcances de la solidaridad}

I. Un buen número de autores ha entendido que el concepto de «solidaridad» no puede reducirse a su contenido económico, como equidistribución de la riqueza entre todas las regiones. Porque la solidaridad no es, en el fondo, sino la consecuencia práctica de un pasado común, construido con las aportaciones de todos, y exigencia de una empresa colectiva proyectada hacia el futuro ${ }^{120}$. Se aduce también al efecto ${ }^{121}$, que en cuanto noción pluridimensional, además de un marcado sentido económico, la solidaridad posee un alcance jurídico y político; por lo mismo, aunque supone la necesidad de un equilibrio económico entre las Comunidades Autónomas, el concepto de solidaridad va más allá, afectando al modo de entender la relación entre los entes territoriales autónomos.

118 BAÑO LEÓN, J.M: Las autonomías territoriales y el principio de uniformidad de las condiciones de vida, op. cit., págs. 179-180. Para este autor, la uniformidad de las condiciones de vida aparece como la concreción del principio de solidaridad.

119 Entre otros, MUÑOZ MACHADO, S: Derecho Público de las Comunidades Autónomas, op. cit., tomo I, pág. 216. Antonio JIMÉNEZ-BLANCO: Las relaciones de funcionamiento..., op. cit., págs. 246-247. ÁLVAREZ CONDE, E: «Solidaridad», en Diccionario del sistema político español, dirigido por J. J. González Encinar, Akal, Madrid, 1984, págs. 854 y ss.; en concreto, pág. 855. También, tiempo atrás, SÁNCHEZ AGESTA, L y GOIG MARTÍNEZ, J.M (revisión y adaptación): «Las Autonomías» (Comentario al Artículo 2), en Comentarios a la Constitución Española de 1978, dirigidos por Oscar Alzaga Villaamil, tomo I, Cortes Generales/Editoriales de Derecho Reunidas, Madrid, 1996, págs. 165 y ss.; en concreto, pág. 229. SANTOLAYA MACHETTI, P (en Descentralización y cooperación, op. cit., pág. 307) ha hablado a su vez de un principio general de actuación.

120 ALONSO DE ANTONIO, J.A: El Estado autonómico y el principio de solidaridad..., op. cit., págs. 377378.

121 GARCÍA ROCA, J: «Asimetrías autonómicas y principio constitucional de solidaridad», op. cit., pág. 73.

UNED. Teoría y Realidad Constitucional, núm. 30, 2012, pp. 139-181. 
A la vista de la enunciación por el art. $2^{\circ}$ de la Constitución del principio de solidaridad no puede descartarse que tal principio desborde el ámbito de lo estrictamente económico, pues sin olvidar el carácter fundante de la nueva organización territorial del Estado con que tal principio, en paralelo al principio de unidad, de modo harto significativo, se presentó en el texto del Anteproyecto de Constitución, es claro que en la redacción definitiva del precepto la solidaridad aparece como un instrumento de articulación y cohesión que posibilita darle un alcance que desborde el estrictamente económico al que conducen los restantes preceptos en que el principio es contemplado. A todo ello habría de añadirse el aspecto axiológico ínsito en la solidaridad, cuestión a la que ya nos referimos con algún detalle, que propicia un mayor despliegue del principio. No han de extrañar por todo lo expuesto las diversas proyecciones que, más allá del plano económico, se han dado a la solidaridad. Sin pretensión de exhaustividad, nos referiremos a algunas de ellas.

La solidaridad, en atención a que entraña la corresponsabilidad de todas las partes que integran un conjunto en los fines colectivos, así como la del conjunto hacia los intereses propios de los miembros, se ha considerado que, desde una perspectiva positiva, fundamenta, primero, la participación de las Comunidades Autónomas en los asuntos del Estado, especialmente en la formación de los actos de voluntad estatal, y después, la cooperación entre los poderes centrales del Estado y las Comunidades Autónomas, en el ejercicio de sus propias competencias y la coordinación en sus respectivas actuaciones ${ }^{122}$. Algún autor, a partir de la consideración de que el concepto constitucional de solidaridad debe ser complementado con el concepto de cooperación, ha llegado a hablar de una «solidaridad cooperante» ${ }^{123}$. Conjugando el principio de solidaridad con el de lealtad al sistema constitucional, principio éste al que nos referiremos más adelante, Montoro Chiner ${ }^{124}$ entresaca como concreciones del juego combinado de uno y otro, la colaboración entre las instancias que componen un Estado policéntrico como el nuestro y la cooperación legislativa, entendida como coparticipación.

Con una amplitud aún mayor, Falcón ${ }^{125}$ ha considerado que el principio de solidaridad encierra una serie de exigencias de coordinación y eficacia, precisando más adelante que la solidaridad, como exigencia de coordinación, supone un deber de lealtad a las decisiones generales, y ello nos lleva directamente al instituto de la Bundestreue, o principio de lealtad federal, que algunos autores vinculan estrechamente con la solidaridad, y en el que nos detendremos algo más a continuación.

122 ALONSO DE ANTONIO, J.A: «El principio de solidaridad en el Estado autonómico. Sus manifestaciones jurídicas», op. cit., pág. 52. También SÁNCHEZ AGESTA, L (en «Las Autonomías», op. cit., pág. 229) siguió literalmente esta posición. Y Alvarez Conde entiende que la simple proclamación del principio de solidaridad constituye un cauce adecuado para profundizar en una línea de interdependencia y participación de funciones, concluyendo que el principio de solidaridad debe ser concebido como un cauce de cooperación y de participación, que tiene un contenido incompleto que debe ser rellenado por los poderes públicos mediante la articulación de las técnicas necesarias. (ÁLVAREZ CONDE, E: «Solidaridad», op. cit., pág. 857).

123 MONTERO RODRÍGUEZ, C: «La solidaridad constitucional y sus problemas en el Estado autonómico», op. cit., pág. 1261.

124 MONTORO CHINER, M.J: «Legislación básica, solidaridad y lealtad al sistema», en Jornadas de Estudio sobre el Título Preliminar de la Constitución, Ministerio de Justicia, Madrid, 1988, Vol. V, págs. 3475 y ss.; en concreto, pág. 3499.

125 FALCÓN Y TELLA, R: La compensación financiera interterritorial, op. cit., pág. 307. 
II. Quizá convenga, a título previo, comenzar refiriéndonos al significado de la Bundestreue, también a veces identificada como bundesfreundliche Verhalten, esto es, comportamiento favorable a la Federación. Aunque se trata de un principio que se remonta en el tiempo mucho más allá de la Alemania organizada políticamente con la Bonner Grundgesetz, ciñéndonos al régimen surgido después de 1945, cabe recordar con Faller ${ }^{126}$, que fue en la llamada Sentencia de la radio, de 28 de febrero de 1961, donde el BVfG (Bundesverfassungsgericht, esto es, el Tribunal Constitucional Federal alemán) sostuvo esta doctrina ${ }^{127}$, que presupone que el «comportamiento favorable a la Federación» no debe comprenderse como una obligación unilateral de los Estados miembros (Länder) respecto al Estado central (Bund), sino como la fidelidad debida por ambas partes (Bund y Länder) al principio federal, o lo que es igual, como dice Schwarz-Liebermann ${ }^{128}$, a la idea según la cual la estructura federal implica la complementariedad de los dos niveles que se respaldan y apoyan mutuamente. El fundamento de todo el orden federal «comunitario» reside así en el reconocimiento del hecho de que la supervivencia de las partes constitutivas de una Federación es, de algún modo, la razón de ser del orden federal, y de ahí la doble obligación, de una parte para los Länder, desde la adecuada comprensión de su propio interés, en virtud de un «enlightened self-interest», de hacer lo que es indispensable en la Federación, para que ésta pueda cumplir su rol, y de otra para la propia Federación, de velar por el bien de quienes la componen, pues en caso contrario, la legitimidad de la Federación dejaría de existir ${ }^{129}$.

Entre nosotros, han sido básica, aunque no únicamente, los administrativistas quienes se han decantado por situar la solidaridad como soporte del principio de lealtad, entendido en el sentido de la Bundestreue germana. Así, Muñoz Machado entiende que el principio de solidaridad tiene una funcionalidad primaria y esencial, como es la de lograr un buen funcionamiento de las estructuras públicas y una correcta articulación de las competencias. Dicho de otro modo, el principio de solidaridad impondría a todos los poderes públicos un comportamiento leal, aceptando las reglas del sistema y procurando su conservación $^{130}$. En una dirección próxima se sitúa Jiménez-Blanco, quien, al margen de otras acepciones, cree que el principio constitucional de solidaridad también puede jugar como sedes materiae de la «Bundestreue española» ${ }^{131}$.

126 FALLER, H.J: «El principio de la lealtad federal en el orden federativo de la República Federal de Alemania», en Revista de Estudios Políticos, nº 16, Julio/Agosto 1980, págs. 197 y ss.; en concreto, págs. 197198.

127 «En el Estado federal alemán — argumenta el BVfG - el conjunto de las relaciones constitucionales entre el Estado central y sus miembros, así como las relaciones constitucionales entre los miembros, están determinados por el principio constitucional no escrito del deber recíproco del Bund y de los Länder a observar un comportamiento favorable a la Federación».

128 SCHWARZ-LIEBERMANN von WAHLENDORF, H.A: «Une notion capitale du droit constitutionnel allemand: la Bundestreue (fidélité fédérale)», en Revue du Droit public, nº 3-1979, Mai/Juin 1979, págs. 769 y ss.; en concreto, pág. 770.

129 Ibidem, pág. 771.

130 MUÑOZ MACHADO, S: Derecho Público de las Comunidades Autónomas, op. cit., tomo I, págs. 216217.

131 JIMÉNEZ-BLANCO, A: Las relaciones de funcionamiento entre el poder central y los entes territoriales, op. cit., pág. 247.

UNED. Teoría y Realidad Constitucional, núm. 30, 2012, pp. 139-181. 
En fin, un último sector doctrinal, ha visto en la solidaridad una suerte de cláusula de cierre del sistema de descentralización territorial del Estado ${ }^{132}$. La solidaridad, a juicio de García Roca, se trataría de un elemento que busca la mediación en un ordenamiento descentralizado con numerosos factores heterogéneos o asimétricos con el fin de generar políticas de consenso, para alcanzar un grado imprescindible de homogeneidad como factor de unidad. Presentaría, pues, una naturaleza mediadora que operaría habitualmente con carácter residual.

III. Unas últimas reflexiones se imponen para finalizar. Hemos de admitir, como ya hemos puesto de relieve, que el principio de solidaridad, aun presentando un contenido esencialmente económico, tiene una operatividad que desborda la propia de ese estricto ámbito. Hasta aquí, nada que objetar; sin embargo, de ahí a que pueda verse en ese principio el fundamento constitucional último de buena parte de los mecanismos de relación entre los entes territoriales característicos de lo que podríamos denominar el federalismo cooperativo, e incluso, en algunos casos, del sistema federal sin más, media una distancia. No creemos que el contenido de este principio pueda llegar a convertirse en casi omnicomprensivo, por amplio que pueda ser. Pero es que, además, algunos de esos mecanismos de relación que un sector de la doctrina ha puesto en estrecha conexión con la solidaridad, se encuentran insertos en la propia lógica del sistema autonómico, por lo que no es necesario buscarles un específico punto de engarce con la Constitución. Recordemos al respecto, que tiempo atrás von Hippel habló de la existencia de unos «principios constitutivos subyacentes al texto constitucional» ${ }^{133}$, entre los que en un Estado federal se había de incluir el «principio de comportamiento amistoso entre sus miembros», esto es, lo que hoy en la República Federal el $B \operatorname{VerfG}$ ha identificado como el bundesfreundlichen Verbalten. Lo que se acaba de decir valdría en sus mismos términos para fundamentar entre nosotros, por ejemplo, el deber general de colaboración a que están sometidos el Estado y las Comunidades Autónomas, que, como ha dicho el Tribunal Constitucional ${ }^{134}$, siguiendo la estela del $B \operatorname{Verf} G$, no es preciso justificar en preceptos concretos, porque se encuentra implícito en la propia esencia de la forma de organización territorial del Estado que se implanta en la Constitución, aunque no sea ocioso recordar que el principio de coordinación se eleva por la norma fundamental a la consideración de uno de los principios de actuación de la Administración pública (art. 103.1 CE) ${ }^{135}$. Ello no significa, por su-

132 LUCAS VERDÚ, P y LUCAS MURILLO DE LA CUEVA. P «La solidaridad interterritorial», op. cit., págs. 464-466. Estos, autores siguen muy de cerca la tesis de García Roca. Cfr. al efecto, GARCÍA ROCA, J: «Asimetrías autonómicas y principio constitucional de solidaridad», op. cit., en especial, págs. 88-90. En una posición no muy alejada, aún partiendo de premisas no precisamente próximas, De Cabo habla de que el sistema de solidaridad encuentra en el art. $2^{\circ} \mathrm{CE}$ una cláusula de seguridad, en el sentido de que autoriza a actuar cuando las otras vías no hayan sido suficientes. (DE CABO MARTÍN, C: Teoría constitucional de la solidaridad, op. cit., pág. 106).

133 Nos lo recuerda BACHOF, O, en «Verfassungswidrige Verfassungsnormen?», en la obra de recopilación de algunos de sus trabajos, Wege zum Rechtstaat. Ausgewählte Studien zum öffentlichen Recht, Athenaum Verlag, Königstein, 1979, págs. 1 y ss. Manejamos la versión española, ¿'Normas constitucionales inconstitucionales?, $2^{\mathrm{a}}$ ed., Palestra Editores, Lima, 2010, pág. 85.

134 SSTC 18/1982, de 4 de mayo, fund. jur. 14, y 80/1985, de 4 de julio, fund. jur. $2^{\circ}$, entre otras muchas.

135 El Tribunal Constitucional ha establecido una diferencia entre los principios de coordinación y de cooperación; mientras este último (que tiende a garantizar la participación de todos los entes involucrados en la 
puesto, que en muchos casos los principios de colaboración y de solidaridad no caminen parejos $^{136}$.

Particular hincapié se ha hecho en la conexión entre el principio de lealtad institucional, que también cabría denominar de lealtad constitucional, que obliga a $\operatorname{todos}^{137}$, y que se perfila como aquel principio que exige de todos los poderes públicos una actuación leal, respetuosa con las reglas vertebradoras del sistema, que bien podríamos considerar que es el trasunto en nuestro ordenamiento de la Bundestreue alemana, y el principio de solidaridad, en el que, supuestamente, aquél encontraría su fundamento último. Aunque no podamos por menos que admitir la similitud de este principio con el que antes mencionábamos de actuación autonómica no contradictoria con el interés general, no creemos que uno y otro principio puedan entrelazarse hasta el extremo de confundirse. Por otro lado, no terminamos de compartir esa percepción de la conexión antes señalada, pues no vemos que tal lealtad haya de sustentarse en cláusula constitucional alguna, ya que nos parece que se encuentra implícita en la propia lógica del sistema constitucional. Además, no creemos que el constituyente estuviera pensando ni de lejos en este significado cuando consagró la solidaridad en el art. $2^{\circ}$. Ello no obstante, hemos de admitir que el Tribunal Constitucional parece en cierto modo haber admitido tal conexión. Ya en su Sentencia 64/1990 el Alto Tribunal visualizó el comportamiento leal entre los poderes territoriales del Estado como una manifestación del principio de solidaridad ${ }^{138}$, recordando a la par que en su jurisprudencia se había referido con reiteración a la existencia de un «deber de auxilio recíproco entre autoridades estatales y autónomas» ${ }^{139}$, y a un «deber de recíproco apoyo y mutua lealtad» ${ }^{140}$, deberes éstos que vendrían a ser la concreción de «un deber general de fidelidad a la Constitución», exigible tanto al Estado como a la Comunidad Autónoma en cuanto medio para hacer viable y facilitar el ejercicio o el mejor fin de las competencias ajenas ${ }^{141}$. Pero no es menos cierto que el Tribunal, al unísono, entendió que estos deberes de recíproco apoyo y mutua lealtad no tenían que justificarse en preceptos concretos, pues eran inherentes a la propia esencia del modelo de organización territorial del Estado implantado por la Constitución. En momentos más próximos en el tiempo, el «intérprete supremo de la Constitución», aún haciendo hincapié en la trascendencia del principio de lealtad constitucional, «un principio esencial en las

toma de decisiones cuando el sistema de distribución competencial conduce a una actuación conjunta del Estado y de las Comunidades Autónomas, según interpretara el Tribunal en su Sentencia 68/1996, de 4 de abril, fund. jur. 10) lo ha conectado «con la idea de la voluntariedad», el de coordinación lo ha vinculado «con la de la imposición». SSTC 194/2004, de 4 de noviembre, fund. jur. 9 ${ }^{\circ}$, y 13/2007, de 18 de enero, fund. jur. $7^{\circ}$. Añadamos, en sintonía con lo ya expuesto, que para el Tribunal, las técnicas de cooperación y colaboración son «consustanciales a la estructura compuesta del Estado de las Autonomías». STC 13/1992, de 6 de febrero, fund. jur. $7^{\circ}$.

136 Así, por ejemplo, en la STC 152/1988, de 20 de julio (fund. jur. $6^{\circ}$ ), el Tribunal, refiriéndose a la conjunción de actividades de las autoridades estatales y autonómicas que ha de llevarse a cabo para la satisfacción del derecho a disfrutar de una vivienda digna y adecuada de todos los españoles (art. $47 \mathrm{CE}$ ), considera que la misma no sólo debe atenerse al respeto estricto de las competencias ajenas, «sino también a los principios de colaboración y solidaridad y, en definitiva, a una exigible actitud de lealtad constitucional».

137 STC 209/1990, de 20 de diciembre, fund. jur. $4^{\circ}$.

138 STC 64/1990, de 5 de abril, fund. jur. $7^{\circ}$, ab initio.

139 STC 18/1982, de 4 de mayo, fund. jur. 14.

140 STC 96/1986, de 10 de julio, fund. jur. $3^{\circ}$.

141 STC 11/1986, de 28 de enero, fund. jur. $5^{\circ}$, in fine. 
relaciones entre las diversas instancias de poder territorial, que constituye un soporte esencial del funcionamiento del Estado autonómico», y subrayando que su observancia resulta obligada ${ }^{142}$, no ha sustentado esta obligatoriedad del principio en ningún precepto constitucional concreto. Por nuestra parte, no nos cabe la más mínima duda de que tales deberes y principios existirían aún en defecto de una específica proclamación constitucional del principio de solidaridad, con el que, desde luego, guardan una estrecha proximidad, pero cuyo fundamento constitucional no ha de encontrarse inexcusablemente en él.

Por lo demás, no toda la doctrina comparte la existencia de esa estrecha conexión entre la solidaridad y la Bundestreue; tal es el caso de Santolaya ${ }^{143}$, quien se ha mostrado partidario de observar con sumo cuidado y precaución la teoría de que la solidaridad es una institución equivalente al principio de «lealtad federal alemana», y ello, fundamentalmente, porque la afirmación de la solidaridad como límite de actuación asume en España un marcado sentido unilateral: límite para las Comunidades Autónomas, pero no para el Estado, lo que podría propiciar la superación de los esquemas formales de distribución de las competencias, pero únicamente para permitir una acción estatal específica. No creemos, sin embargo, que el principio de solidaridad en sí mismo considerado pueda operar como fuente atributiva de una competencia estatal autónoma, lo que no significa que no pueda, e incluso deba, ser tenido en cuenta al hilo del ejercicio de determinadas competencias estatales. Por poner un ejemplo, el principio de solidaridad, como ya se dijo, puede habilitar al Estado para ejercer su potestad de planificación de la actividad económica, que el Estado podrá ejercitar con base en su competencia ex art. 149.1.13ª CE; será esta norma y no la acogida por el art. 138.1 la que habilite la actuación del Estado.

El Tribunal Constitucional se ha referido a esta cuestión tanto desde la óptica de las competencias autonómicas, como desde la de las estatales. Desde esta última perspectiva, el Alto Tribunal ha considerado que la acción estatal debe desplegarse teniendo en cuenta las peculiaridades de un sistema de autonomías territoriales, en el que hay competencias de otros entes que han de respetarse, y es claro que no se respeta este esquema cuando se tratan de crear competencias concurrentes o «paralelas», al amparo, además, de un precepto tan genérico como el art. $9^{\circ} .2$ de la Constitución que, «entendido como una habilitación para que el Estado pueda actuar en razón del interés general, podría terminar por vaciar de contenido el diseño constitucional del Estado de las Autonomías» ${ }^{144}$.

Mutatis mutandis, a nuestro entender, este razonamiento puede proyectarse en sus propios términos sobre el principio de solidaridad. No otra es, a nuestro modo de ver, la interpretación del Tribunal. Así, en la STC 29/1986, admite que los planes de reindustrialización referidos a determinadas zonas (las zonas de urgente reindustrialización) especialmente afectadas por la reconversión industrial, suponen la concreción de un «esfuerzo nacional de solidaridad» que, para ser efectivo, debe concertarse en ámbitos geográficos limitados a definir desde una perspectiva supracomunitaria; la atribución a las diferentes Comunidades Autónomas con competencias en la materia de la facultad de crear esas zonas y elaborar los planes relativos a cada una de ellas, por separado, impediría

142 SSTC 239/2002, de 11 de diciembre, fund. jur. 11, y 13/2007, de 18 de enero, fund. jur. $7^{\circ}$, in fine. 143 SANTOLAYA MACHETTI, P: Descentralización y cooperación, op. cit., pág. 308.

144 STC 146/1986, de 25 de noviembre, fund. jur. $4^{\circ}$. 
esa concentración de esfuerzos. Es por lo mismo por lo que el Tribunal sostiene la competencia estatal para la declaración de esas zonas de urgente reindustrialización. Es obvio que el Tribunal atiende a la solidaridad, cuando se refiere a ese necesario «esfuerzo nacional de solidaridad», pero la competencia estatal no se justifica en el principio de solidaridad, sino en las exigencias del principio de unidad económica ${ }^{145}$.

En la misma dirección, pero aún con mayor claridad, al ocuparse de la encomienda al Estado por el art. 138.1 CE de la realización efectiva del principio de solidaridad, el Tribunal Constitucional ha precisado ${ }^{146}$ que tal precepto no puede ser considerado, en sentido estricto, como una norma atributiva de competencia estatal. Ello no conduce a reducirlo al carácter de un precepto programático, o tan siquiera al de elemento interpretativo de las normas competenciales. Es, por el contrario, un precepto con peso y significado propios, que debe ser interpretado, eso sí, en coherencia con las normas competenciales que resultan de la Constitución y de los Estatutos de Autonomía. El Tribunal ha reiterado esta doctrina en diversos momentos, ampliándola incluso en relación al art. 139 CE, como en la STC 128/1999, en la que recuerda que tales preceptos no contienen atribución competencial alguna ${ }^{147}$, si bien, en armonía con la doctrina fijada unos años antes, tales artículos han de informar las reglas atributivas de competencias, que deben ser interpretadas de acuerdo con el contenido de los mismos ${ }^{148}$. En definitiva, el art. 138.1, al otorgar al Estado la garantía de la realización efectiva del principio de solidaridad, no atribuye una competencia específica que el Estado pueda ejercer frente a las Comunidades Autónomas ${ }^{149}$, lo que no significa que carezca de cualquier efecto, pues habrá de informar las reglas atributivas de competencias, operando de este modo con una virtualidad hermenéutica.

C) La interpretación en sede constitucional de este principio

Hasta aquí, hemos tenido oportunidad de referirnos a determinadas tomas de postura jurisprudenciales en relación, directa o indirecta, con el principio de solidaridad. No es cuestión lógicamente de volver a reiterar lo ya expuesto. Nos limitaremos pues, a sistematizar algunas ideas dispersas y a hacernos eco de algunos aspectos no tratados de la doctrina constitucional en torno a este principio.

a) El Alto Tribunal, en una de sus primeras sentencias ${ }^{150}$, señaló que aunque las Comunidades Autónomas no son ni pueden ser ajenas al interés general del Estado, la defensa específica de éste es atribuida por la Constitución al Gobierno (arts. 97, 155), llamado asimismo prioritariamente a velar por la efectiva realización del principio de solidaridad (art. 138), junto a las Cortes Generales (art. 158.2). Jiménez de Parga, a la sazón Presidente del Tribunal, cuestionaría esta interpretación en su Voto particular a la

145 STC 29/1986, de 20 de febrero, fund. jur. $4^{\circ}$.

146 STC $146 / 1992$, de 16 de octubre, fund. jur. $1^{\circ}$.

147 STC 128/1999, de 1 de julio, fund. jur. $6^{\circ}$.

148 STC 52/1988, de 24 de marzo, fund. jur. $3^{\circ}$.

149 Análoga doctrina ha fijado el Tribunal en relación al deber de recíproco apoyo y mutua lealtad, con base al cual, no pueden resultar ampliadas las competencias estatales, ni es posible por lo mismo limitar o condicionar el ejercicio de las competencias autonómicas. STC 96/1986, de 10 de julio, fund. jur. $3^{\circ}$.

150 STC $25 / 1981$, de 14 de julio, fund. jur. $3^{\circ}$. 
STC 14/2004 ${ }^{151}$, considerando que no era oportuno ni conveniente retener esta tesis, que venía a entrañar que las Comunidades Autónomas quedaban en una posición secundaria en el cumplimiento de la solidaridad. Sin embargo, el Tribunal ha dejado muy claro en su doctrina, que sobre las Comunidades Autónomas pesa una clara obligación de velar por el principio de solidaridad en el marco de sus propias competencias. Que asuman un protagonismo menor que el del Estado es perfectamente comprensible a la vista de que es al Estado a quien la Constitución (art. 138.1) encomienda garantizar la realización efectiva del principio de solidaridad. Y que ello sea así, no requiere de muchas explicaciones. Es el Estado el garante de la unidad, pues la diversidad viene dada por la estructura territorial compleja, quedando la consecución del interés general de la Nación confiada a los órganos generales del Estado ${ }^{152}$, y en lo que se refiere a la estructura y funcionamiento de la actividad económica, su marco jurídico fundamental requiere la existencia de unos principios básicos del orden económico que han de aplicarse con carácter unitario y general en todo el territorio nacional. De ahí que la unicidad del orden económico nacional, como ha dicho el Tribunal Constitucional ${ }^{153}$, sea un presupuesto necesario para que el reparto de competencias entre el Estado y las distintas Comunidades Autónomas en materias económicas no conduzca a resultados disfuncionales y desintegradores. Y de ahí igualmente que la LOFCA atribuya al Estado (art. $2^{\circ} .1, \mathrm{~b} /$ ) la garantía del equilibrio económico, a través de la política económica general, de acuerdo con lo establecido en los arts. 40.1, 131 y 138 de la Constitución. En resumen, la consecución del interés general de la Nación, confiada a los órganos generales del Estado, determina que éste haya de garantizar la realización efectiva del principio de solidaridad ${ }^{154}$.

b) El Tribunal ha dejado meridianamente claro, que aunque el principio de solidaridad no sea fuente atributiva de competencias, no ya para las Comunidades Autónomas, sino tampoco para el Estado, como ha precisado en su interpretación del art. 138.1 CE, tal principio está lejos de ser un mero principio programático, vinculando por el contrario a todos los poderes públicos, y no sólo al Estado, sin que pueda entenderse que se oponga a esta conclusión la mención que el art. 138.1 CE hace del Estado como garante del principio de solidaridad, ni la reserva al Estado de la competencia exclusiva para regular las condiciones básicas que garanticen la igualdad de todos los españoles en el ejercicio de los derechos y en el cumplimiento de los deberes constitucionales (art. 149.1, $1^{\mathrm{a}}$ CE), o el expreso encargo de adoptar las medidas oportunas para conseguir el desarrollo armónico entre las diversas partes del territorio español que el art. $2^{\circ}$ LOFCA asigna asimismo al Estado ${ }^{155}$. No ha de extrañar que, en coherencia con esta vinculatoriedad inmediata, el Tribunal haya recordado, que un Estatuto de Autonomía no puede contener criterios que desvirtúen o limiten la atribución al Estado de la garantía del principio de solidaridad $^{156}$.

151 STC 14/2004, de 12 de febrero. Voto particular que formula el Presidente, don Manuel Jiménez de Parga y Cabrera, punto $1^{\circ}$.

152 STC 42/1981, de 22 de diciembre, fund. jur. $2^{\circ}$.

153 Entre otras varias, en la STC 96/2002, de 25 de abril, fund. jur. 11.

154 STC 16/2003, de 30 de enero, fund. jur. $5^{\circ}$, in fine.

155 STC 150/1990, de 4 de octubre, fund. jur. 11.

156 STC 31/2010, de 28 de junio, fund. jur. 131. 
c) Que los principios de igualdad material y solidaridad no entrañen por sí mismos una atribución competencial a las Comunidades Autónomas, que carecen de competencia específica para desarrollarlos con cualquier alcance, no obsta para que éstas puedan, e incluso deban, por mandato constitucional, estatutario y legal, atender a la realización de tales principios en el ejercicio de sus competencias propias ${ }^{157}$. De esta forma, es perfectamente legítimo que el art. $2^{\circ} .2$ LOFCA obligue expresamente a cada Comunidad Autónoma a velar por su propio equilibrio territorial y por la realización interna del principio de solidaridad (solidaridad intraterritorial). Y no contradice tal determinación, según el Tribunal ${ }^{158}$, el hecho de que las Cortes Generales, en el desarrollo de las previsiones constitucionales y de la LOFCA, interpreten el principio de solidaridad en el reparto del Fondo de Compensación Interterritorial (hoy habría que decir de los Fondos) que ellas deben efectuar en el sentido de remediar también desequilibrios intraterritoriales, pues ello queda dentro de las facultades del legislador estatal, en virtud de la habilitación constitucional del art. 158.2 CE. En armonía con esta obligación autonómica de velar por su propio equilibrio territorial y por la realización dentro de su territorio del principio de solidaridad, el Juez de las leyes admitió como indiscutible la competencia de Cataluña (que además tiene competencia exclusiva en materia de régimen local, sin perjuicio de lo establecido por el art. 149.1, $18 \mathrm{CE}$ ) para crear un «Fondo de Cooperación Local», integrado por las participaciones de los Entes locales en ingresos del Estado y de la Generalidad, que habría de repartir atendiendo a las peculiaridades específicas de los Entes locales de su territorio. Todo ello sin perjuicio de que la distribución hubiera de hacerla respetando los criterios de reparto establecidos por el Estado, cuando se tratara de ingresos estatales ${ }^{159}$, y aplicando los criterios que la propia Comunidad Autónoma estableciera cuando se tratara de participación en ingresos propios ${ }^{160}$.

d) El régimen económico y fiscal de Canarias ha propiciado algunos pronunciamientos de indudable interés en relación con el principio de solidaridad. El Tribunal ha partido $^{161}$ del sentido esencialmente finalista de tal régimen, en cuanto integrado por un conjunto de elementos (no exclusivamente fiscales) de carácter rigurosamente instrumental, en cuanto que son puros medios para conseguir un fin (art. 138.1 CE), que no es otro que el de la realización efectiva del principio de solidaridad atendiendo precisamente al hecho insular. Del propio art. 138.1 deriva también el Juez de las leyes el carácter evolutivo del régimen económico-fiscal canario ${ }^{162}$, en cuanto que dicho precepto no se refiere simplemente al hecho insular, sino «a las circunstancias del hecho insular». Y si el hecho insular es perfectamente invariable, las «circunstancias» sociales y económicas que lo ro-

157 SSTC 150/1990, de 4 de octubre, fund. jur. 11, y 13/2007, de 18 de enero, fund. jur. $7^{\circ}$.

158 STC $183 / 1988$, de 13 de octubre, fund. jur. $5^{\circ}$, in fine.

159 Como recuerda el Tribunal en su Sentencia 237/1992, incumbe al Estado, a través de la actividad legislativa, hacer efectivos y conjugar el principio de suficiencia de las Haciendas locales y el de solidaridad y equilibrio territorial (arts. 138 y $142 \mathrm{CE}$ ) y a ello viene que le corresponda el señalamiento de los criterios para el reparto de la participación que se les conceda en los ingresos estatales. STC 237/1992, de 15 de diciembre, fund. jur. $6^{\circ}$.

160 STC 331/1993, de 12 de noviembre, fund. jur. $3^{\circ}$, B) in fine.

161 STC 16/2003, de 30 de enero, fund. jur. $5^{\circ}$, a), in fine.

162 Esta doctrina sería reiterada en las SSTC 62/2003, de 27 de marzo, fund. jur. 5º y 109/2004, de 30 de junio, fund. jur. $3^{\circ}$. 
dean, no. De ello deriva el carácter fundamentalmente evolutivo de tal régimen. A partir de esta premisa, y siguiendo en el ámbito del art. 138.1 CE, se entiende que el equilibrio económico a que el mismo alude exige ponderar, en cada momento, el hecho insular, pero también los datos relativos a las demás partes del territorio español. Es decir, el principio de solidaridad no opera sólo en la dirección del régimen económico-fiscal canario, sino también en función de las circunstancias de la totalidad del territorio español. $\mathrm{Y}$ es que, como en otro momento ha puesto de relieve el Tribunal ${ }^{163}$, la virtualidad propia del principio constitucional de solidaridad, que aspira a unos resultados globales para todo el territorio español, recuerda la técnica de los vasos comunicantes.

e) El sistema de financiación de las Comunidades Autónomas ha sido considerado por el Tribunal «el vehículo a través del cual se articula el principio de solidaridad interterritorial», razón por la cual, no sólo le corresponde al Estado garantizar, de conformidad con el art. $138 \mathrm{CE}$, la realización efectiva del principio de solidaridad, sino que las Comunidades Autónomas vienen obligadas por la LOFCA (art. $2^{\circ} .1$, e/) a coordinar el ejercicio de su actividad financiera con la Hacienda del Estado de acuerdo, entre otros, al principio de «solidaridad entre las diversas nacionalidades y regiones». Corresponde asimismo al Estado, ex art. 149.1.14 CE en su conexión con los arts. 138.1 y 157.3 CE, regular el ejercicio de las competencias financieras de las Comunidades Autónomas y fijar los niveles de su contribución a la nivelación y a la solidaridad. En este contexto, el Tribunal ha entendido ${ }^{164}$, que la determinación de cuál sea el esfuerzo fiscal que hayan de realizar las Comunidades Autónomas es cuestión que sólo corresponde regular al propio Estado, tras las actuaciones correspondientes en el seno del sistema multilateral de cooperación y coordinación constitucionalmente previsto. En sintonía con esta doctrina, el Alto Tribunal iba a declarar la inconstitucionalidad del inciso del art. 206.3 del Estatuto de Cataluña, que preveía que la aportación de la Generalitat a la solidaridad y a la nivelación de servicios respecto de las demás Comunidades Autónomas se realizaría «siempre y cuando (esas otras Comunidades Autónomas) lleven a cabo un esfuerzo fiscal también similar». El Tribunal entiende que ésta es una exigencia que, en ningún caso, puede imponer el Estatuto a las demás Comunidades Autónomas, pues al hacerlo así se vulneran, a la vez, las señaladas competencias del Estado y el principio de autonomía financiera de aquellas otras Comunidades Autónomas, autonomía financiera que el art. 156.1 CE conecta expresamente con el principio de coordinación con la Hacienda estatal. En definitiva, el respeto a las competencias del Estado como garante de la solidaridad interterritorial en el ámbito económico y financiero no permite la imposición estatutaria de condiciones imperativas.

f) Un principio que el Tribunal ha considerado inherente al modelo de solidaridad interterritorial es el de que el «equilibrio económico adecuado y justo» que el Estado viene constitucionalmente obligado a procurar entre las Comunidades Autónomas, no perjudique a las más prósperas más allá de lo razonablemente necesario para el fin de la promoción de las menos favorecidas. Esta doctrina iba a ser sentada por el Tribunal al hilo de la impugnación de la previsión del art. 206.5 del Estatuto de Cataluña, que prevé que 
«(e)l Estado garantizará que la aplicación de los mecanismos de nivelación no altere en ningún caso la posición de Cataluña en la ordenación de rentas per capita entre las Comunidades Autónomas antes de la nivelación». De ser considerada esta norma como la imposición estatutaria de una condición imperativa frente al Estado, debería haber sido declarada inconstitucional y nula, pero no iba a ser ésa su interpretación. Por el contrario, el Tribunal iba a entender que tal norma no es una cláusula de naturaleza imperativa, sino tan sólo la expresión reiterada de un deber que para el Estado trae causa inmediata y directa de la propia Constitución, que le impone la garantía de la realización efectiva del principio de solidaridad «velando por el establecimiento de un equilibrio económico, adecuado y justo entre las diversas partes del territorio español» (art. 138.1 CE). «Adecuación y justicia que — como bien dice el Tribunal ${ }^{165}$ — predicadas del equilibrio económico al que ha de ordenarse la realización de la solidaridad entre las Comunidades Autónomas garantizada por el Estado, no pueden redundar para las más ricas en mayor perjuicio que el inherente a toda contribución solidaria para con las menos prósperas en orden a una aproximación progresiva entre todas ellas, excluyéndose por tanto, el resultado de la peor condición relativa de quien contribuye respecto de quien se beneficia de una contribución que dejaría entonces de ser solidaria y servir al fin del equilibrio para propiciar, en cambio, un desequilibrio de orden distinto al que se pretende corregir». En consecuencia, el Tribunal considera el art. 206.5 del Estatuto de Cataluña, como la manifestación expresa de un principio inherente al propio modelo de solidaridad interterritorial $^{166}$.

g) La interdicción de que las diferencias entre los Estatutos de Autonomía puedan implicar privilegios económicos o sociales no impone, a juicio del Tribunal ${ }^{167}$, una homogeneidad absoluta en dichos ámbitos, pues ello iría contra el criterio del apartado 1 del mismo artículo, que configura el principio de solidaridad como instrumento para alcanzar un «equilibrio económico adecuado y justo entre las diversas partes del territorio español». Por tanto, lo que la Constitución proscribe son las diferencias que carezcan de justificación objetiva y razonable, conllevando beneficios que otras Comunidades Autónomas, en las mismas circunstancias, no podrían obtener. En sintonía con esta interpretación, el Tribunal ha rechazado la tacha de inconstitucionalidad aducida en el recurso contra el Estatuto de Autonomía de Cataluña contra al primer inciso de su art. 201.4, que enuncia el principio de que la financiación de la Generalitat no debe implicar efectos discriminatorios para Cataluña, en base a que el mismo responde directamente, a contrario, a lo establecido por el art. 138.2 CE.

El Tribunal Constitucional ha sido más bien timorato a la hora de enfrentarse a la interpretación del principio de solidaridad. Sólo quien fuera uno de sus Presidentes, don Manuel Jiménez de Parga, en su Voto particular a la Sentencia 14/2004, se mostró de-

165 Ibidem.

166 Bien es verdad que para ello el Tribunal ha de recurrir a la técnica de la interpretación conforme, entendiendo que la garantía del Estado a que se refiere el art. 206.5 del Estatuto de Cataluña sólo operará cuando la alteración de la posición de la Comunidad Autónoma de Cataluña se debiera, no a la aplicación general de los mecanismos de nivelación, sino exclusivamente a la aportación que realizase Cataluña como consecuencia de su posible participación en dichos mecanismos». Con ese limitado alcance, así interpretado, el precepto no es considerado contrario a la Constitución.

167 STC 31/2010, de 28 de junio, fund. jur. 131. 
cididamente combativo en orden a la potenciación jurídica de este principio. Ello no obstante, con el paso del tiempo el Tribunal ha ido efectuando aportes dignos de ser tenidos en cuenta (destacando particularmente la STC 31/2010), con los que ha contribuido a aclarar, en alguna medida, el significado de un principio que se caracteriza por sus múltiples proyecciones, por su polivalencia, un principio que a nuestro entender debiera ser potenciado en cuanto que es uno de los más significativos del Welfare State, y que debiera estar llamado a desempeñar una función significativa en períodos de una tan profunda crisis del Estado social como el que ahora atravesamos.

$$
\text { *** }
$$

TITLE : The solidarity like constitutional principle

RESUMEN : El art. $2^{\circ}$ de la Constitución establece el principio de solidaridad como un principio general de organización del Estado. Sin embargo, a la vista de otros preceptos constitucionales, hay que decir que el principio presenta un contenido esencialmente económico. Con todo, limitar el contenido del principio constitucional de solidaridad a lo estrictamente económico, esto es, a una equidistribución de la riqueza entre todas las regiones, sería una interpretación errónea. En efecto, el principio de solidaridad es un principio polivalente. $Y$ así, es también un valor del ordenamiento constitucional y puede asimismo entenderse como una cláusula general que exige atender al interés común y no sólo al propio, en el ejercicio por los entes territoriales de sus respectivas competencias. No creemos que el contenido de este principio sea ilimitado, pero es cierto que el principio de solidaridad puede vincularse con algunos de los principios característicos que subyacen en el Estado federal o regional, como el de lealtad federal (la Bundestreue alemana) o el deber general de colaboración entre el Estado y las Comunidades Autónomas.

ABSTRACT : The Art. 2 Constitution establishs the principle of solidarity as an general principle of organization of the State. Nevertheless, at the sight of other constitutional articles we must to say that it presents an essentially economic content. Even so, to confine the constitutional solidarity principle's content to the strictly economic, that is, to a balanced distribution of the wealth between all the regions, it would be an erroneous interpretation. Indeed, the solidarity principle is a polyvalent principle. It is likewise a value of the constitutional order and, in like manner, it may be understood as a general clause that requires to meet the common interest and not only the own in the performance by the territorial bodies of its own scopes. We do not think that the content of this principle be unlimited, but it is true that the solidarity principle may be linked with some characteristic underlying principles of the federal or regional State such as the loyalism federal (the german Bundestreue) or the general obligation of collaboration between the State and the Autonomus Communities.

Palabras Clave : Autonomía, Estado social, Fondo de Compensación Interterritorial, Lealtad federal (Bundestreue), Principio de solidaridad, Solidaridad, Unidad.

KEY WORDS : Self-government, Welfare State, Interterritorial Compensation Fund, Federal loyalty (Bundestreue), Solidarity's principle, Solidarity, Unity.

FECHA DE RECEPCIÓN: 11.04.2012 FECHA DE ACEPTACIÓN: 19.07.2012

UNED. Teoría y Realidad Constitucional, núm. 30, 2012, pp. 139-181. 